\title{
Spatial and temporal variability of biophysical variables in southwestern France from airborne L-band radiometry
}

\author{
E. Zakharova ${ }^{1}$, J.-C. Calvet ${ }^{1}$, S. Lafont ${ }^{1}$, C. Albergel ${ }^{1, *}$, J.-P. Wigneron ${ }^{2}$, M. Pardé ${ }^{3}$, Y. Kerr ${ }^{4}$, and M. Zribi ${ }^{4}$ \\ ${ }^{1}$ CNRM-GAME, Météo-France, CNRS - URA1357, 42 avenue Gaspard Coriolis, Toulouse, France \\ ${ }^{2}$ INRA, EPHYSE, 71 avenue Edouard Bourlaux, Villenave d'Ornon, France \\ ${ }^{3}$ LATMOS/CNRS, Route de Troux, 78280 Guyancourt, France \\ ${ }^{4}$ CESBIO, CNES/CNRS/IRD/UPS - UMR5126, 18 Avenue Edouard Belin, Toulouse, France \\ * now at: ECMWF, Shinfield Park, Reading, UK
}

Correspondence to: J.-C. Calvet (jean-christophe.calvet@meteo.fr)

Received: 5 January 2012 - Published in Hydrol. Earth Syst. Sci. Discuss.: 17 January 2012

Revised: 30 May 2012 - Accepted: 31 May 2012 - Published: 25 June 2012

\begin{abstract}
In 2009 and 2010 the L-band microwave Cooperative Airborne Radiometer for Ocean and Land Studies (CAROLS) campaign was performed in southwestern France to support the calibration and validation of the new Soil Moisture and Ocean Salinity (SMOS) satellite mission. The Lband Microwave Emission of the Biosphere (L-MEB) model was used to retrieve surface soil moisture (SSM) and the vegetation optical depth (VOD) from the CAROLS brightness temperature measurements. The CAROLS SSM was compared with in situ observations at 11 sites of the SMOSMANIA (Soil Moisture Observing System-Meteorological Automatic Network Integrated Application) network of MétéoFrance. For eight of them, significant correlations were observed $(0.51 \leq r \leq 0.82)$, with standard deviation of differences ranging from $0.039 \mathrm{~m}^{3} \mathrm{~m}^{-3}$ to $0.141 \mathrm{~m}^{3} \mathrm{~m}^{-3}$. Also, the CAROLS SSM was compared with SSM values simulated by the A-gs version of the Interactions between Soil, Biosphere and Atmosphere (ISBA-A-gs) model along 20 flight lines, at a resolution of $8 \mathrm{~km} \times 8 \mathrm{~km}$. A significant spatial correlation between these two datasets was observed for all the flights $(0.36 \leq r \leq 0.85)$. The CAROLS VOD presented significant spatial correlations with the vegetation water content (VWC) derived from the spatial distribution of vegetation types used in ISBA-A-gs and from the Leaf Area Index (LAI) simulated for low vegetation. On the other hand, the CAROLS VOD presented little temporal changes, and no temporal correlation was observed with the simulated LAI. For low vegetation, the ratio of VOD to VWC tended to decrease, from springtime to summertime. The ISBA-A-gs grid cells
\end{abstract}

$(8 \mathrm{~km} \times 8 \mathrm{~km})$ were sampled every $5 \mathrm{~m}$ by CAROLS observations, at a spatial resolution of about $2 \mathrm{~km}$. For $83 \%$ of the grid cells, the standard deviation of the sub-grid CAROLS SSM was lower than $0.05 \mathrm{~m}^{3} \mathrm{~m}^{-3}$. The presence of small water bodies within the ISBA-A-gs grid cells tended to increase the CAROLS SSM spatial variability, up to $0.10 \mathrm{~m}^{3} \mathrm{~m}^{-3}$. Also, the grid cells characterised by a high vegetation cover heterogeneity presented higher standard deviation values, for both SSM and VOD.

\section{Introduction}

Biophysical variables, such as soil moisture, Leaf Area Index (LAI), and vegetation biomass, need to be monitored for applications in ecohydrology, hydrometeorology and agroclimatology, at global and regional scales. Soil moisture plays an important role in hydrological models, controlling the soil drainage and the surface runoff. It is also a crucial variable for land surface models (LSM), as it regulates the water and energy surface fluxes (e.g. Mohr et al., 2000). Finally, the seasonal dynamics of vegetation properties, such as LAI, is connected to soil moisture dynamics (Kochendorfer and Ramirez, 2010). This is particularly true in regions affected by droughts, where water is a limiting factor of plant growth (Porporato and Rodriguez-Iturbe, 2002). Developing observation capacities able to monitor the spatial and temporal variability of vegetation and soil moisture characteristics at 
a regional scale, is needed for ecohydrology research (Wang et al., 2012).

This remote sensing study investigates the joint soil moisture and vegetation growth dynamics using the L-band Cooperative Airborne Radiometer for Ocean and Land Studies (CAROLS, Zribi et al., 2011). The analysis is based on a very high number of flights (20 flights covering the same transect), in situ soil moisture observations, and simulated biophysical variables. The CAROLS campaign was performed in the framework of the calibration/validation of the SMOS (Soil Moisture and Ocean Salinity) spaceborne radiometer operating at L-band (Kerr et al., 2001). Over land, the main product of SMOS is surface soil moisture (SSM). The multi-angular bipolarized observations of SMOS permit the retrieval of the vegetation optical depth (VOD), in addition to SSM (Wigneron et al., 1995; Lee et al., 2002; Pellarin et al., 2003a). The satellite-derived SSM or soil wetness index (SWI) products from passive (e.g. the Advanced Microwave Scanning Radiometer on EOS - AMSR-E) and active (the Advanced Scatterometer - ASCAT, and the European Remote Sensing Satellite Scatterometer - ERS-Scat) Cband microwave sensors were recently validated over southwestern France (Albergel et al., 2009; Pellarin et al., 2006; Rüdiger et al., 2009), Western Africa (Gruhier et al., 2010; de Rosnay et al., 2009), Canada and Ukraine (Wagner et al., 1999a,b), China (Zhao et al., 2008), the United States of America (Drusch et al., 2004) and Australia (Draper et al., 2007). Microwave sensors operating at low frequencies (1$10 \mathrm{GHz}$ ) are particularly useful for SSM monitoring. Compared to higher frequencies, low frequencies are able to sample thicker surface soil layers. Moreover, the vegetation masking effect are less pronounced, and atmospheric effects are weaker (Wagner et al., 2007).

The high capability of SSM retrieval at L-band (1-2 GHz) was demonstrated by several studies (e.g. Wigneron et al., 2002; Kerr et al., 2001; de Rosnay et al., 2006; Calvet et al., 2011). The first ground-based studies dedicated to soil moisture measurement at L-band started in the 1970s (Njoku and Kong, 1977). Later, they were complemented by airborne measurements (Jackson et al., 1986; Schmugge et al., 1992; Chanzy et al., 1997), which finally led to the development the SMOS (Soil Moisture and Ocean Salinity) spaceborne instrument operating at L-band (Kerr et al., 2001).

A number of field experiments (CoSMOS, SMOSREX, VAS, MELBEX-1, ELBARA-ETH) (Saleh et al., 2007, 2009; Cano et al., 2010) were carried out in order to prepare the SMOS mission. In addition, several airborne campaigns were performed to assess SSM retrieval over large areas: EuroSTARRS in France and Spain (Saleh et al., 2004), NAFE/CoSMOS in Australia (Panciera et al., 2008), EAGLE2006 in Germany (Su et al., 2009), HOBE in Denmark (Bircher et al., 2012). These studies showed that the response of L-band brightness temperatures to SSM is affected by biomass conditions (Saleh et al., 2004). They also showed the importance of specific biome calibration of the parameters of the L-band Microwave Emission of the Biosphere model (L-MEB) (Bircher et al., 2012). The L-MEB model simulates the L-band emission of the soil-plant system (Wigneron et al., 2007), and the SMOS SSM retrieval algorithm is based on the inversion of L-MEB. The L-MEB SSM retrieval capability was extensively tested in homogeneous vegetation cover conditions (Grant et al., 2008; Saleh et al., 2007; Wigneron et al., 2007; Guglielmetti et al., 2008). Panciera et al. $(2008,2009)$ found that after site-specific calibration of the vegetation and roughness parameters, the SSM retrieval accuracy can be better than $0.048 \mathrm{~m}^{3} \mathrm{~m}^{-3}$ for crops and grasslands. After the launch of SMOS, there is now a need to assess the accuracy of SSM retrievals for various ground properties and vegetation types in the framework of the calibration/validation of the instrument.

Besides SSM, the retrieval algorithm based on L-MEB produces a L-band VOD. In this study, VOD is defined as the effective zenith (i.e. nadir) opacity of the vegetation (" $\tau$ ", dimensionless) in the microwave domain. A number of studies have shown the usefulness of VOD values retrieved from C-band or X-band satellite microwave brightness temperatures (Liu et al., 2007, 2011; Jones et al., 2011; Miralles et al., 2011). At L-band, this quantity can be produced by the inversion of the simplified " $\tau-\omega$ " approach used in the LMEB model (Wigneron et al., 2007). When $\mathrm{VOD}=0$, there is no vegetation attenuation of the soil microwave emission. The VOD value tends to increase with the vegetation water content (VWC, in $\mathrm{kg} \mathrm{m}^{-2}$ ). From L-band to X-band, VOD is proportional to VWC and to frequency $(f)$ (Jackson and Schmugge, 1991; Schmugge and Jackson, 1992; Kerr and Wigneron, 1995; Njoku and Chan, 2006). The VOD value is often expressed as VOD $=b$ VWC, with $b=A \varepsilon_{\mathrm{S}}^{\prime \prime} f$ (Kirdyashev et al., 1979), where the value of $A$ is related to the canopy structure, and $\varepsilon_{S}^{\prime \prime}$ is the imaginary part of the dielectric constant of saline water in the vegetation. The latter depends only slightly on temperature, at the low salinity levels generally observed in plants. At low frequencies, it is often assumed that the $A \times \varepsilon_{\mathrm{S}}^{\prime \prime}$ product does not vary much from one vegetation type to another and across frequency values, and that $b$ is proportional to $f$. For example, the frequency used by the SMOS radiometer is $1.42 \mathrm{GHz}$ (L-band) and the C-band and X-band channels of AMSR-E correspond to $6.925 \mathrm{GHZ}$ and $10.65 \mathrm{GHz}$, respectively. Therefore, if one assumes that $f$ dominates the VOD response to VWC, VOD is about 5 times more sensitive to VWC at C-band than at Lband, even more at $\mathrm{X}$-band. Using ground multi-frequency passive microwave observations, Calvet et al. (2011) have shown that $\mathrm{C}$-band and $\mathrm{X}$-band are more appropriate than Lband to monitor the VWC of a wheat field, with VWC values up to $3 \mathrm{~kg} \mathrm{~m}^{-2}$ at the end of May. This is consistent with the lower sensitivity of VOD to changes in VWC (i.e. the lower $b$ value) at L-band.

One of the more recent airborne campaigns dedicated to SMOS is the CAROLS experiment, co-funded by CNES and ESA. CAROLS was performed in 2009 and 2010 in 
southwestern France and in Spain (Zribi et al., 2011; Pardé et al., 2011a). Albergel et al. (2011) showed the good sensitivity of the CAROLS L-band brightness temperatures $(\mathrm{Tb})$ to the SSM variability at 11 stations of the SMOSMANIA soil moisture network (Calvet et al., 2007; Albergel et al., 2008), with an average Pearson correlation coefficient of -0.76 at nadir. However, radio frequency interferences (RFI) affected the CAROLS observations (Albergel et al., 2011; Pardé et al., 2011a; Zribi et al., 2011).

In this study, the temporal and spatial variability of the SSM and VOD values retrieved by L-MEB from 2009 and 2010 springtime CAROLS Tb observations in southwestern France is investigated. Details on the parameterisation of the L-MEB model are given in Pardé et al. (2011b). In a first stage, post-processing techniques are used to limit the detrimental impact on the retrievals of RFI and open water surfaces. Then, the accuracy of the SSM retrievals is assessed using in situ SSM observations at 11 instrumented sites. The CAROLS SSM and VOD transects are compared with SSM and Leaf Area Index (LAI) simulations of the $\mathrm{CO}_{2}$-responsive version of the Interactions between Soil, Biosphere and Atmosphere (ISBA-A-gs) model, over $8 \mathrm{~km} \times 8 \mathrm{~km}$ grid cells.

\section{Data and methods}

\subsection{The CAROLS data}

\subsubsection{The CAROLS instrument}

The CAROLS L-band microwave radiometer is fully polarimetric and has two antennas: one looking at nadir and a sidelooking antenna slanting with an incidence angle of $33.5^{\circ}$. The sampling frequency range is $1.401-1.426 \mathrm{GHz}$, and an advanced analogue filter permits the suppression of the main RFI affecting the Tb. The instrument sensitivity is $0.1 \mathrm{~K}$ for $1 \mathrm{~s}$ integration time, and the stability is better than $0.1 \mathrm{~K}$ over $15 \mathrm{~min}$. The internal calibration is achieved by load and noise diodes. The radiometer was calibrated during test flights performed in November 2008 (Zribi et al., 2011).

\subsubsection{The 2009 and 2010 flights in southwestern France}

The CAROLS microwave $\mathrm{Tb}$ airborne measurements were carried out from the French ATR-42 research aircraft, together with infrared temperature $\left(T_{\mathrm{IR}}\right)$ observations performed by a CIMEL radiometer. The flights consisted of straight lines between Toulouse and the Atlantic coast (Bay of Biscay), then to the Mediterranean coast, and back to Toulouse (Fig. 1). The observations were performed at an altitude of $2000 \mathrm{~m}$ a.s.l. (above sea level), and the ground footprint sizes of the nadir and side-looking antennas were about $1.4 \mathrm{~km}$ and $2.1 \mathrm{~km}$, respectively (Albergel et al., 2011). The areas observed by the two antennas formed a swath with a mean width of about $3 \mathrm{~km}$. The high acquisition rate of the

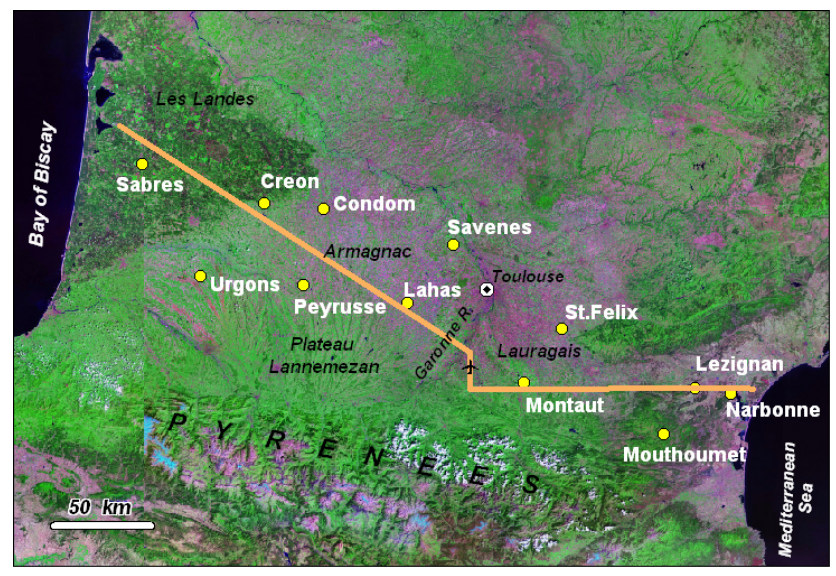

Fig. 1. Atlantic-Mediterranean transect and location of SMOSMANIA stations (background is a Landsat GeoCover Mosaics).

instrument allowed oversampling the swath, with an alongtrack spatial resolution of about $5 \mathrm{~m}$. The transect between the Bay of Biscay and the Mediterranean Sea was about $385 \mathrm{~km}$, and the complete flights were covered in $3 \mathrm{~h}$.

In 2009, six CAROLS flights were conducted over southwestern France between 28 April and 27 May, and all of them are used in this study. While half of them (28 April, 15 and 27 May) covered the whole transect, the others $(18,20$ and 26 May) only covered the Toulouse-Atlantic coast transect (225 km long). Moreover, 14 flights performed in 2010, covering the full transect between 15 April and 1 July, are used in this study.

Four flights (18 and 27 May 2009, 4 and 22 June 2010) were performed in the late afternoon (between 18:00 UTC and 20:00 UTC). All the other flights were performed in the morning (between 05:00 UTC and 08:00 UTC). The flights did not cover mountainous areas, and the surface altitude varied between $0 \mathrm{~m}$ a.s.l. and $400 \mathrm{~m}$ a.s.l.

The transect can be divided into three main areas:

- the Atlantic lowland plain, between $1^{\circ} \mathrm{W}$ and $0.2^{\circ} \mathrm{W}$, corresponding to Les Landes pine forest, on sandy soils (with sand fractions of about $90 \%$ ).

- the Garonne plain, between $0.2^{\circ} \mathrm{W}$ and $2.1^{\circ} \mathrm{E}$, corresponding to hilly Armagnac, Garonne terraces and Lauragais regions: It is characterized by undulating terrain, intersected by numerous rivers, and mainly covered by croplands (e.g. wheat and irrigated maize), by grassland and forest patches over the steepest slopes, and with areas covered by vineyards. This part of the transect presents the highest altitudes (from $150 \mathrm{~m}$ to $380 \mathrm{~m}$ ). The loamy soils are characterised by a higher clay content $(20-30 \%)$, in comparison with the surrounding regions, and a sand fraction ranging between $20 \%$ and $30 \%$. 
- the Mediterranean plain, between $2.1^{\circ} \mathrm{E}$ and $3.3^{\circ} \mathrm{E}$ is flat and the vegetation cover is contrasted, with forest patches alternating with sparse vegetation, dry shrubs, and vineyards. In the easternmost part the soils are more sandy, with sand fractions ranging from $40 \%$ to $50 \%$.

\subsubsection{SSM and VOD retrievals}

The SSM and VOD values were retrieved from the biangular/dual-polarized L-band CAROLS Tb measurements, inverting the most recent version of the L-MEB model (Panciera et al., 2008; Pardé et al., 2011a,b). According to the Fresnel law, TbV and $\mathrm{TbH}$ values are confounded at nadir, and only three independent $\mathrm{Tb}$ values are used in the inversion: $\mathrm{Tb}$ at nadir, and slant $\left(33.5^{\circ}\right) \mathrm{TbV}$ and $\mathrm{TbH}$. The present version uses the Dobson model (Dobson et al., 1985) of the soil microwave dielectric properties. The soil roughness is accounted for using the Wang and Choudhury (1981) model, based on two parameters: $h$ and $Q$. The $Q$ parameter is set to zero, and the $h$ parameter is related to SSM as proposed by Saleh et al. (2007) for a grassland site in southwestern France, and applied by Pardé et al. (2011b) to the CAROLS data:

$h=1.3-1.13 \times \mathrm{SSM}$

with SSM in units of $\mathrm{m}^{3} \mathrm{~m}^{-3}$.

The vegetation contribution is computed using the $\tau-\omega$ approach, where $\tau$ represents VOD, and $\omega$ represents the single scattering albedo of the vegetation, assumed to be close to zero (Wigneron et al., 2007). The effective temperature ( $\left.T_{\text {eff }}\right)$ contribution is approximated as

$T_{\text {eff }}=T_{\text {depth }}+\left(T_{\mathrm{IR}}-T_{\text {depth }}\right) \times(\mathrm{SSM} / w)^{\beta}$

where $T_{\text {depth }}$ is the ground temperature at a depth of $30 \mathrm{~cm}$ measured at the meteorological stations of the SMOSMANIA network (see Sect. 2.2) and then interpolated along the aircraft transect, and $T_{\mathrm{IR}}$ is the infrared temperature, remotely sensed from the aircraft. The $w$ and $\beta$ parameters have constant values: $0.30 \mathrm{~m}^{3} \mathrm{~m}^{-3}$ and 0.3 , respectively (Grant et al., 2008; Wigneron et al., 2007, 2008). The soil properties like the sand and clay contents used in the model are derived from the SMOSMANIA auxiliary dataset (Albergel et al., 2008) linearly interpolated along the CAROLS flight transect.

\subsubsection{Mitigation of perturbing factors}

In southwestern France the CAROLS microwave measurements are affected by RFI and by the presence of water bodies. Albergel et al. (2011) had to filter out about half of CAROLS Tb observations affected by RFI, over 11 SMOSMANIA sites. The RFI tend to increase the $\mathrm{Tb}$ values and undetected RFI may result in the underestimation of SSM and/or in the overestimation of VOD. The structure and quality of the CAROLS observations, as well as the RFI sources and their detection, were described in detail by Pardé et al. (2011a) and Zribi et al. (2011). Before applying the SSM and VOD retrieval algorithm, a method of detection and mitigation of the undesirable effects of RFI was applied to the CAROLS Tb dataset by Pardé et al. (2011a). The analysis of the SSM and VOD products performed in this study showed that further RFI filtering is needed.

As illustrated by Fig. 2, a number of unrealistic SSM values, close to $1 \mathrm{~m}^{3} \mathrm{~m}^{-3}$ or higher than $1 \mathrm{~m}^{3} \mathrm{~m}^{-3}$, as well as a lot of smaller peaks are obtained. The spatial analysis of the successful SSM retrievals shows that the perturbation of SSM values are obtained over areas where (1) very low $\mathrm{Tb}$ values and/or (2) significant differences between nadir $\mathrm{V}$ - and $\mathrm{H}$-polarized $\mathrm{Tb}$ are observed ( $\mathrm{TbV}$ and $\mathrm{TbH}$, respectively). In order to improve the retrievals, a post-processing filtering technique was applied to the data set. Two methods were used: (1) a physical method based on the fact that $\mathrm{TbH}$ and $\mathrm{TbV}$ should be close at nadir and (2) a statistical method using 2-D histograms.

The physical method was based on the paired view analysis of $\mathrm{TbV}$ and $\mathrm{TbH}$ at nadir. According to the Fresnel law, the surface emissivities at vertical and horizontal polarizations are equal at nadir. Therefore, the difference between nadir $\mathrm{TbH}$ and nadir $\mathrm{TbV}(\Delta \mathrm{Tb})$ should not deviate much from zero. It was assumed that all the retrievals corresponding to $\Delta \mathrm{Tb}$ values higher or lower than \pm 2 standard deviations (calculated using all 20 flights) were affected by RFI. Filtering the data using this criterion removed many peaks around the largest urban areas.

The statistical method was based on the analysis of $\mathrm{TbH}$ vs. TbV at $33.5^{\circ}$ for the 2009 flights (Fig. 3). A density-based clustering of the data (Jain et al., 1999) was applied to contour a main cluster A (Fig. 3), and remove the data outside this cluster. The detection of the cluster borders depends on a density threshold, which was determined using the 2009 data, in order to optimize the spatial correlation between the retrieved and the modelled SSM values. The same threshold was used for the 2010 data.

The spatial analysis of the outliers corresponding to high $\mathrm{TbH}$ and to high $\mathrm{TbV}$ values (B and $\mathrm{C}$ subsets of Fig. 3, respectively) indicates that they are caused by unmitigated RFI perturbations close to urban areas (not shown). The D cluster corresponds to low values of both $\mathrm{TbH}$ and $\mathrm{TbV}$, observed in regions presenting a high density of water bodies (not shown). In order to further reduce the impact of open water surfaces, we have arbitrarily excluded the cluster A measurements corresponding to $\mathrm{TbH}$ values less than $220 \mathrm{~K}$. It removed all the unrealistic SSM higher than $1 \mathrm{~m}^{3} \mathrm{~m}^{-3}$ (Fig. 2). The application of the above-mentioned post-processing filtering techniques improved significantly the overall quality of the SSM and VOD retrieval data set. 

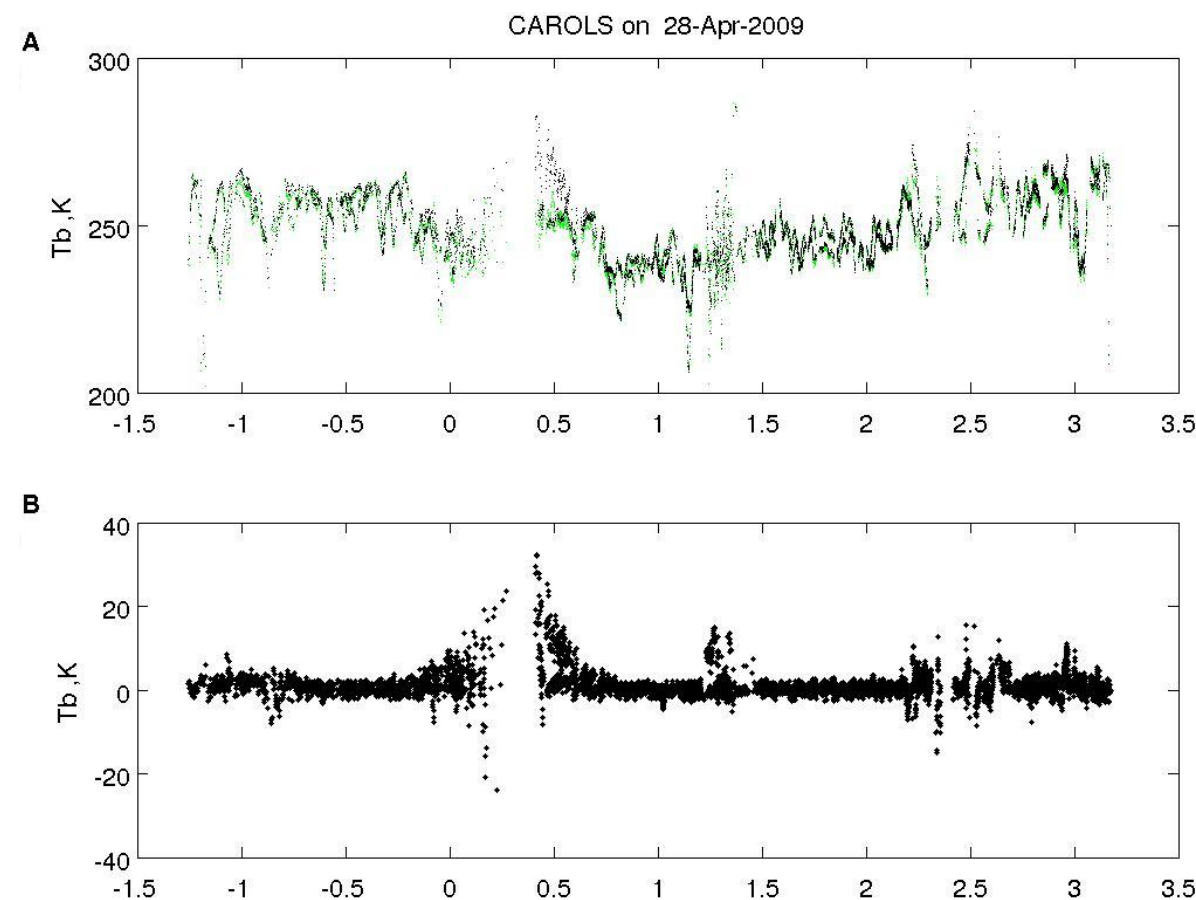

c

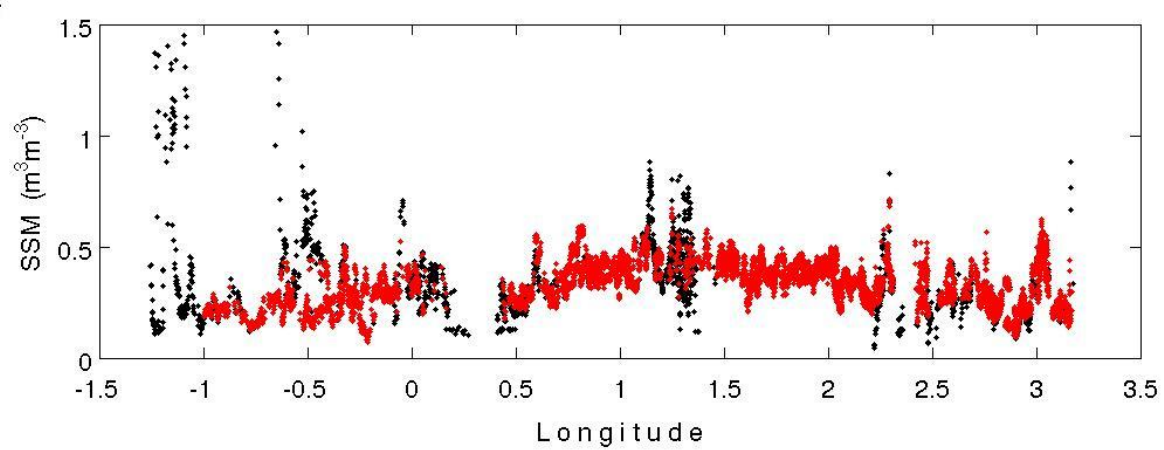

Fig. 2. Spatial variability of (A) CAROLS TbH (green) and TbV (black) at nadir, (B) CAROLS brightness temperature difference (TbV$\mathrm{TbH}$ ) at nadir, and (C) CAROLS surface soil moisture (SSM), for 28 April 2009. Red dots represent the SSM data after the post-processing filtering.

\subsection{SMOSMANIA stations}

The SSM retrievals were validated using in situ observations of the Soil Moisture Observing System - Meteorological Automatic Network Integrated Application (SMOSMANIA) network (Calvet et al., 2007). This network consists of 21 stations in southern France, of which 12 have been operating in southwestern France since January 2007. It is based on the existing automatic weather station network of Météo-France, and soil moisture profiles are monitored, in addition to standard hydrometeorological observations (precipitation, air temperature, air humidity, wind speed). The stations form a transect between the Atlantic coast and the Mediterranean sea (Fig. 1) and sample soil moisture under contrasting climatic conditions (Albergel et al., 2008).
At each station, the soil moisture acquisition is done every $12 \mathrm{~min}$ by four ThetaProbe ML2X instruments at $5 \mathrm{~cm}$, $10 \mathrm{~cm}, 20 \mathrm{~cm}$ and $30 \mathrm{~cm}$ depths. Soil temperature is measured at the same depths. The soil moisture dataset is available online at http://www.ipf.tuwien.ac.at/insitu/. The observations from this network were extensively used for the validation of modelled and satellite-derived soil moisture (Albergel et al., 2008, 2009, 2010, 2011; Parrens et al., 2012).

\subsection{ISBA-A-gs surface soil moisture and LAI simulations}

In order to assess the ability of the CAROLS measurements to represent the spatial and temporal variability of SSM and VOD, the retrievals were compared with SSM and LAI 


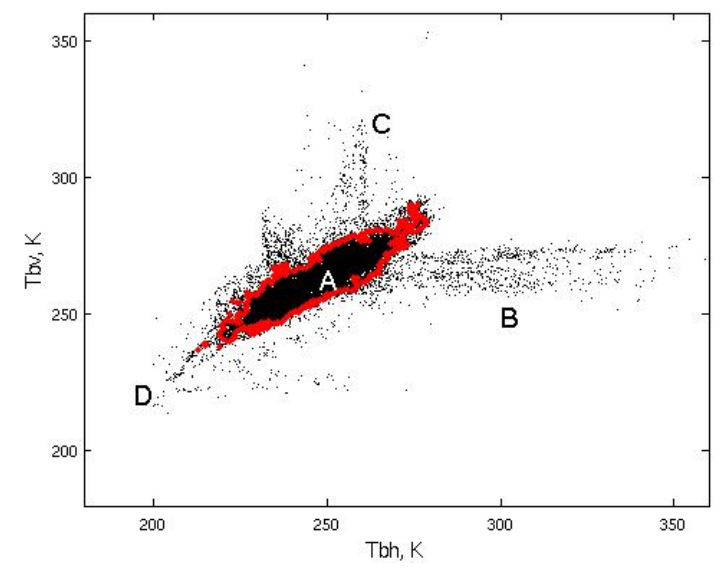

Fig. 3. Side-looking antenna TbV vs. TbH for the six CAROLS flights in 2009. The measurements outside of the red contour were removed from the analysis. The A-D letters correspond to data clusters in the $\mathrm{TbH}-\mathrm{TbV}$ space. The main cluster A (except for $\mathrm{TbH}<220 \mathrm{~K})$ corresponds to the data analyzed in Sects. 3-4. Clusters B-D correspond to observations excluded from the dataset: $\mathrm{B}$ and $\mathrm{C}$ are related to unmitigated RFI perturbations close to urban areas; $\mathrm{D}$ is related to a high density of water bodies.

simulations produced by the ISBA-A-gs LSM, at a spatial resolution of $8 \mathrm{~km} \times 8 \mathrm{~km}$.

Prior to the comparison, the airborne observations were averaged within each ISBA-A-gs grid cell crossed by the flight line. As $\mathrm{Tb}$ values are very sensitive to open water surfaces, the grid cells with water fraction more than $0.8 \%$ (corresponding to a total open water area of $0.5 \mathrm{~km}^{2}$ ) were removed.

The SSM and LAI simulations were carried out using the SURFEX (SURFace Externalisée) platform developed at Météo-France. ISBA-A-gs is a version of the ISBA LSM that includes a photosynthesis and a plant growth model (Calvet et al., 1998, 2004; Calvet, 2000; Calvet and Soussana, 2001). The simulations were driven by the SAFRAN analysis of surface meteorological variables (Durand et al., 1993; Quintana-Segui et al., 2008), and the spatial distribution of the model parameters was based on ECOCLIMAP-II (Masson et al., 2003; Faroux et al., 2009).

The ISBA-A-gs version used in this study simulates three soil layers. The simulated SSM corresponds to the modelled surface soil layer, about $1 \mathrm{~cm}$ thick. The sub-grid heterogeneity is represented by aggregating the simulations performed for the various surface types found in the grid cell, according to the surface type fractions provided by ECOCLIMAP-II (Faroux et al., 2009; Brut et al., 2009). Also, this allows to provide separate estimates of SSM and LAI for high (trees) and low (grasslands and crops) vegetation types.

The LAI simulations of ISBA-A-gs can be used, to some extent, to estimate the VWC affecting the L-band land emission. In a study at a global scale, Pellarin et al. (2003a) assumed that the VWC of low vegetation (grasslands and crops) could be estimated as $\mathrm{VWC}_{\text {low }}=0.5 \times \mathrm{LAI}$, in units of $\mathrm{kg} \mathrm{m}^{-2}$. For high (forest) canopies they set constant values of $\mathrm{VWC}_{\text {high }}$, as at L-band this quantity depends mostly on the water content of the branches. The latter was estimated by Pellarin et al. (2003a) as $3 \mathrm{~kg} \mathrm{~m}^{-2}$ and $4 \mathrm{~kg} \mathrm{~m}^{-2}$ for coniferous and deciduous trees, respectively. As lower branch water content values were reported by Grant et al. (2008) for European forests, the $1.5 \mathrm{~kg} \mathrm{~m}^{-2}$ and $3 \mathrm{~kg} \mathrm{~m}^{-2}$ VWC values are used in this study for coniferous and deciduous trees, respectively. Using the LAI simulated by ISBA-A-gs for low vegetation, and the ECOCLIMAP-II forest fraction, the vegetation water content affecting the L-band land emission for low and high vegetation (in $\mathrm{kg} \mathrm{m}^{-2}$ ) is estimated along the aircraft transect as

$\mathrm{VWC}_{\text {low }}=0.5 \times \mathrm{LAI}_{\text {low }}$
$\mathrm{VWC}_{\text {high }}=1.5 \times \alpha_{\text {conif }}+3 \times \alpha_{\text {decid }}$

where $\mathrm{LAI}_{\text {low }}$ is the LAI of low vegetation in a given grid cell, and $\alpha_{\text {conif }}$ and $\alpha_{\text {decid }}$ are coniferous and deciduous forest fractions, respectively. As shown by Eq. (3b), $\mathrm{VWC}_{\text {high }}$ does not depend on LAI and does not present seasonal variations. This is coherent with ground observations of the Lband microwave emission of forest canopies showing little or no change across seasons (e.g. Guglielmetti et al., 2008; Grant et al., 2008). Finally, VOD can be derived from VWC as

$$
\begin{aligned}
& \mathrm{VOD}_{\text {low }}=b_{\text {low }} \mathrm{VWC}_{\text {low }} \\
& \mathrm{VOD}_{\text {high }}=b_{\text {high }} \mathrm{VWC}_{\text {high }}
\end{aligned}
$$

where $b_{\text {low }}$ and $b_{\text {high }}$ are constant values, for a given vegetation type. Pellarin et al. (2003a) proposed $b_{\text {low }}$ values ranging from 0.15 to $0.20 \mathrm{~m}^{2} \mathrm{~kg}^{-1}$ for low vegetation (crops and grasslands, respectively), and $b_{\text {high }}=0.33 \mathrm{~m}^{2} \mathrm{~kg}^{-1}$. Grant et

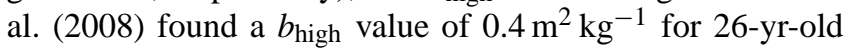
pine trees. Also, values of $b_{\text {high }}$ and $b_{\text {low }}$ can be obtained by inverting Eq. (4) for the flights presenting a significant spatial correlation between VWC and VOD, with VWC and VOD estimates derived from ISBA-A-gs and from CAROLS, respectively, for grid cells with a fraction of woody vegetation higher than $70 \%$, and with a fraction of low vegetation higher than $80 \%$, respectively (see Sect. 3.2.2). Using these average values of $b_{\text {high }}$ and $b_{\text {low }}$, aggregated bottom-up VOD values can be calculated from the ISBA-A-gs model for each flight: the VWC and VOD values derived from Eqs. (3)(4) for low and for high vegetation are aggregated over each ISBA-A-gs grid cell using a linear mixing equation based on the ECOCLIMAP-II vegetation fractions.

\subsection{Investigating the ISBA-A-gs sub-grid variability using the CAROLS retrievals}

While the ground footprint of the CAROLS radiometer is about $1.4 \mathrm{~km}$ at nadir, its along-track spatial resolution allows sampling $\mathrm{Tb}$ every $5 \mathrm{~m}$. Each ISBA-A-gs grid cell 
Table 1. Comparison of SSM time series for (from left to right) SMOSMANIA vs. CAROLS, CAROLS vs. ISBA-A-gs, and ISBA-A-gs vs. SMOSMANIA. The Pearson correlation coefficient ( $r$ ), p-value, RMSD, bias (SMOSMANIA minus CAROLS, CAROLS minus ISBAA-gs, ISBA-A-gs minus SMOSMANIA, respectively) and the standard deviation of differences (SDD) are given for the pooled 2009 and 2010 CAROLS flights.

\begin{tabular}{|c|c|c|c|c|c|c|}
\hline Station & $r$ & p-value & $\begin{array}{l}\text { RMSD } \\
\left(\mathrm{m}^{3} \mathrm{~m}^{-3}\right)\end{array}$ & $\begin{array}{l}\text { Mean bias } \\
\left(\mathrm{m}^{3} \mathrm{~m}^{-3}\right)\end{array}$ & $\begin{array}{l}\text { SDD } \\
\left(\mathrm{m}^{3} \mathrm{~m}^{-3}\right)\end{array}$ & $N_{\text {obs }}$ \\
\hline SBR & $0.36 / 0.54 / 0.69$ & $\mathrm{NS} / * / * * *$ & $0.069 / 0.064 / 0.069$ & $-0.024 /-0.034 / 0.058$ & $0.065 / 0.056 / 0.037$ & 20 \\
\hline URG & $0.56 / 0.50 / 0.64$ & $* / * / * *$ & $0.212 / 0.077 / 0.168$ & $0.195 /-0.046 /-0.149$ & $0.085 / 0.063 / 0.080$ & 20 \\
\hline CRD & $0.66 / 0.55 / 0.68$ & $* * / * / * * *$ & $0.102 / 0.069 / 0.092$ & $-0.080 /-0.005 / 0.085$ & $0.063 / 0.069 / 0.036$ & 20 \\
\hline PRG & $0.23 / 0.58 / 0.67$ & $\mathrm{NS} / * * / * *$ & $0.175 / 0.157 / 0.067$ & $-0.012 /-0.028 / 0.040$ & $0.175 / 0.157 / 0.055$ & 17 \\
\hline $\mathrm{CDM}$ & $0.41 / 0.61 / 0.61$ & $\mathrm{NS} / * * / * *$ & $0.134 / 0.090 / 0.085$ & $0.088 /-0.018 /-0.070$ & $0.101 / 0.090 / 0.050$ & 17 \\
\hline LHS & $0.62 / 0.73 / 0.59$ & $* * / * * * / * *$ & $0.108 / 0.101 / 0.064$ & $0.030 /-0.009 /-0.021$ & $0.105 / 0.101 / 0.062$ & 20 \\
\hline SVN & $0.51 / 0.46 / 0.58$ & $* / * / * *$ & $0.212 / 0.213 / 0.068$ & $-0.159 / 0.154 / 0.005$ & $0.141 / 0.150 / 0.068$ & 20 \\
\hline MNT & $0.82 / 0.63 / 0.64$ & $* * * / * * / * *$ & $0.121 / 0.067 / 0.150$ & $0.113 / 0.032 /-0.144$ & $0.044 / 0.060 / 0.044$ & 17 \\
\hline SFL & $0.67 / 0.74 / 0.53$ & $* * / * * * / *$ & $0.073 / 0.066 / 0.074$ & $-0.017 /-0.018 / 0.029$ & $0.071 / 0.065 / 0.069$ & 17 \\
\hline MTM & $0.80 / 0.72 / 0.54$ & $* * * / * * / *$ & $0.066 / 0.064 / 0.039$ & $0.038 /-0.031 /-0.012$ & $0.054 / 0.057 / 0.038$ & 17 \\
\hline LZC & - & - & - & - & - & 2 \\
\hline $\mathrm{NBN}$ & $0.67 / 0.60 / 0.66$ & $* * I^{*} / * *$ & $0.039 / 0.044 / 0.043$ & $-0.006 /-0.020 / 0.023$ & $0.039 / 0.040 / 0.036$ & 17 \\
\hline Average & $0.57 / 0.61 / 0.62$ & - & $0.119 / 0.097 / 0.084$ & $0.015 /-0.002 /-0.014$ & $0.086 / 0.083 / 0.052$ & - \\
\hline
\end{tabular}

NS - non significant; ${ }^{*},{ }^{* *},{ }^{* * *}$ stand for p-value greater than 0.05 , between 0.05 and 0.01 , between 0.01 and 0.001 , and below 0.001 , respectively.

$(8 \mathrm{~km} \times 8 \mathrm{~km})$ may contain up to about 500 CAROLS retrievals. After the pre- and post-processing filtering, about 60 valid SSM and VOD retrievals are obtained, on average. This oversampling capability was used to investigate the subgrid variability of the model's parameters in grid cells.

\subsection{Satellite LAI product}

In this study, the CAROLS-derived VOD was compared with the version 1 of the GEOLAND2 LAI product (Baret et al., 2012). This product is based on an algorithm trained with two satellite data streams: MODIS, and SPOT/VEGETATION. The fused algorithm uses the SPOT/VEGETATION data to produce the final LAI values. The initial 10 -day, $1 \times 1 \mathrm{~km}$ satellite-derived LAI product was resampled to the SAFRAN $8 \times 8 \mathrm{~km}$ spatial resolution for the 2009 and 2010 years.

\subsection{Metrics used for the comparison of the various data sets}

In order to quantify the differences between two independent estimates of the same quantity (SSM or VOD, either through time at given locations, or throughout the CAROLS transect at given days), four scores are considered in this study: the Pearson correlation coefficient $(r)$, the root mean square difference (RMSD), the standard deviation of differences (SDD) and the Fisher's F-test p-value. If the two estimates to be compared present the same mean value, then SDD is equal to RMSD. Otherwise, SDD is lower than RMSD as the latter is impacted by the bias. The p-value indicates the significance of the test: if it is small (e.g. below 0.05), it means that the correlation is not a coincidence. In this study, the following thresholds on p-values are used: (i) NS (non significant) for p-value greater than 0.05 , (ii) * between 0.05 and 0.01 , (iii) ${ }^{* *}$ between 0.01 and 0.001 , (iv) ${ }^{* * *}$ between 0.001 and 0.0001 and $(\mathrm{v})^{* * * *}$ below a value of 0.0001 .

\section{Results}

\subsection{CAROLS SSM validation at the SMOSMANIA stations}

In order to evaluate the accuracy of the airborne L-band SSM retrievals, the latter were compared with in situ soil moisture observations performed at a depth of $5 \mathrm{~cm}$ at the 12 SMOSMANIA stations located in southwestern France (Fig. 4 and Table 1). It must be noted that the Lézignan-Corbières station (LZC) did not provide SSM observations during the airborne campaign of 2010. Therefore, only 11 stations are considered. For this comparison, the SSM retrievals were averaged over a $10 \mathrm{~km}$ radius zone around each station. Significant correlations ( $p$-value $<0.05$ ) between airborne and in situ observations are found for 8 out of 11 stations. For the three other stations, Sabres (SBR), Peyrusse-Grande (PRG) and Condom (CDM), discrepancies are observed and the correlation of the CAROLS SSM retrievals with ground observations is not significant (Table 1). More often than not, at PRG and CDM stations, the CAROLS SSM retrievals are lower than the in situ data (Fig. 4). However, PRG presents one SSM retrieval much higher than the in situ observations, and the mean bias is slightly negative, in conjunction with a high SDD value of $0.18 \mathrm{~m}^{3} \mathrm{~m}^{-3}$. 

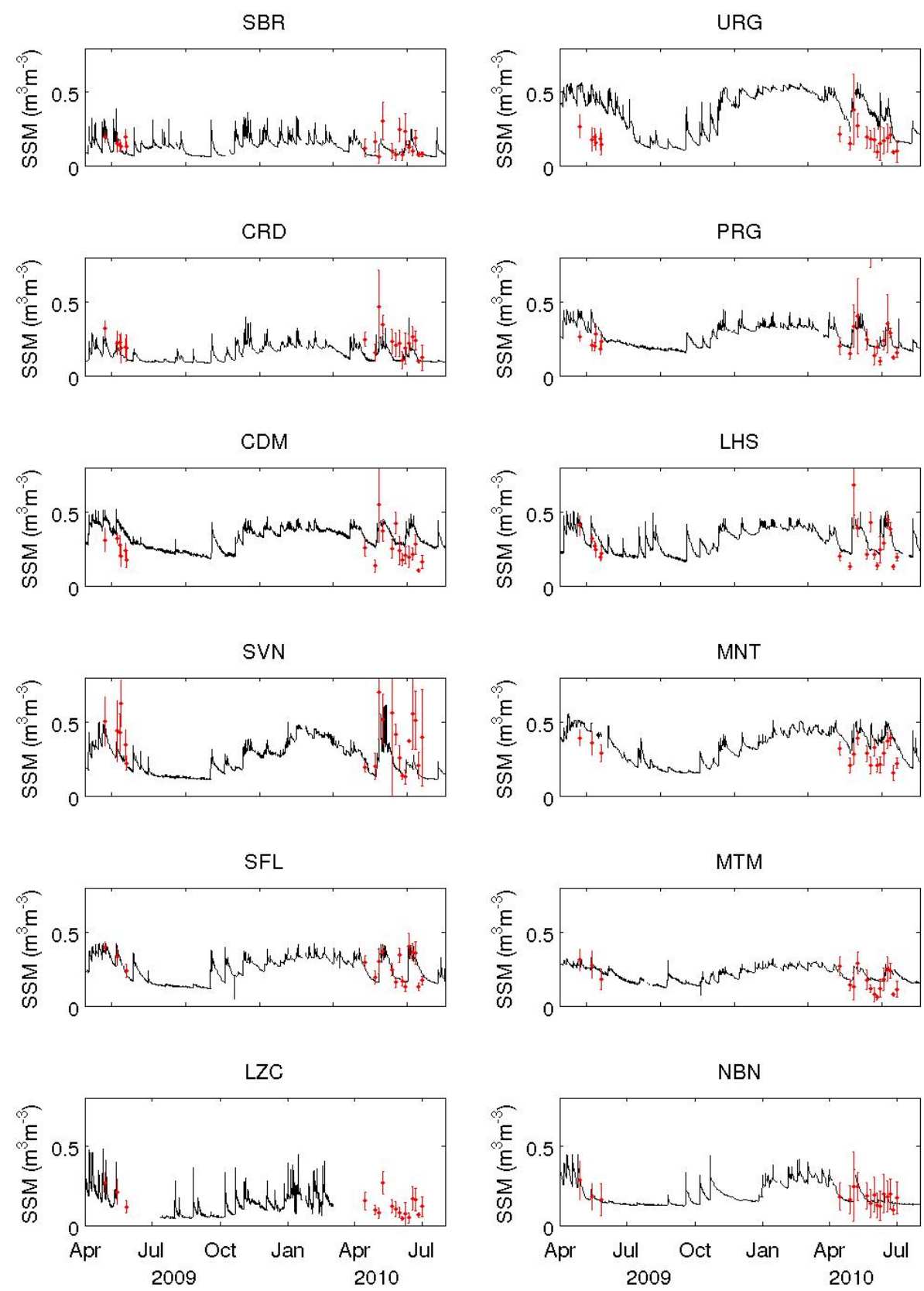

Fig. 4. Temporal variability of the SSM measured by the SMOSMANIA stations (black line) and of the CAROLS SSM (red dots with std error bars): SBR - Sabres, URG - Urgons, CRD - Créon d'Armagnac, PRG - Peyrusse-Grande, CDM - Condom, LHS - Lahas, SVN Savenes, MNT - Montaut, SFL - Saint-Félix de Lauragais, MTM - Mouthoumet, LZC - Lézignan-Corbières, NBN - Narbonne.

The most marked CAROLS biases $\left(0.19 \mathrm{~m}^{3} \mathrm{~m}^{-3}\right.$ and $-0.16 \mathrm{~m}^{3} \mathrm{~m}^{-3}$ ) vs. in situ observations are observed for the Urgons (URG) and Savenes (SVN) stations. As both stations are far from the CAROLS flight transect, it is likely that the station soil properties differ from those seen by the L-band radiometer. This explanation does not hold for the Montaut (MNT) station, which presents a marked bias $\left(0.12 \mathrm{~m}^{3} \mathrm{~m}^{-3}\right)$ while lying very close to the CAROLS transect. Moreover, the highest Pearson correlation coefficient $(r=0.82)$ is obtained for this station. The MNT station is located in a hilly area, and while the SSM in situ measurements at this station represent well the SSM temporal variability of the area, topographical effects impact the spatial variability of SSM.

In Table 1, the CAROLS SSM retrievals are compared, also, with the ISBA-A-gs SSM simulations at the $8 \mathrm{~km} \times 8 \mathrm{~km}$ grid cells covering the SMOSMANIA stations. For the sake of comparison, they are compared with the in 
situ observations. CAROLS presents fair correlations with ISBA-A-gs for all the stations. While, for the eastern stations (MNT, SFL, MTM, NBN), the CAROLS SSM correlates better with the in situ observations than ISBA-A-gs, systematically higher SDD values are obtained with CAROLS. On average, the CAROLS SDD scores are higher than $0.08 \mathrm{~m}^{3} \mathrm{~m}^{-3}$. The ISBA-A-gs SSM is closer to the in situ observations, with $\mathrm{SDD}=0.052 \mathrm{~m}^{3} \mathrm{~m}^{-3}$, on average. The lower average SDD between the model and in situ observations is associated with a better average correlation (0.62, against 0.57 for CAROLS).

\subsection{Observed and modelled spatial and temporal variability of biophysical variables along the CAROLS transect}

The ISBA-A-gs LSM simulates SSM, together with the rootzone soil moisture, as prognostic variables. Also, the vegetation growth component of the model provides LAI simulations. The simulated SSM and LAI are expected to correlate with the SSM and VOD values retrieved from the CAROLS $\mathrm{Tb}$, both temporally and spatially. Figure 5 presents the SSM and LAI time series simulated by ISBA-A-gs, together with the precipitation provided by SAFRAN, over the Atlantic-Mediterranean transect (Fig. 1), for the 20092010 period. The three regions described in Sect. 2.1.2 can be distinguished in both SSM and LAI time series. Higher SSM values are simulated for the Garonne central part of the transect, in relation to a higher soil water holding capacity. Higher LAI values are simulated over the Atlantic evergreen Les Landes pine forest, at the western part of the transect $\left(3.5 \mathrm{~m}^{2} \mathrm{~m}^{-2}\right.$ in April, at the beginning of the 2009 and 2010 CAROLS campaigns, and close to $5 \mathrm{~m}^{2} \mathrm{~m}^{-2}$ at the end of May 2009 and June 2010). In the central and eastern parts of the transect, the simulated LAI varies between $1.1 \mathrm{~m}^{2} \mathrm{~m}^{-2}$ and $4 \mathrm{~m}^{2} \mathrm{~m}^{-2}$, from the beginning to the end of the 2009 and 2010 CAROLS campaigns. The simulated leaf onset varies from the end of February in Les Landes forest to the end of March in other areas. Figure 5 also shows the satellitederived LAI values. The latter present lower and smoother annual peak values than the simulated LAI.

\subsubsection{Surface soil moisture}

The various CAROLS flights permitted the sampling of a large range of SSM conditions, as illustrated by the SSM values simulated by ISBA-A-gs in Fig. 5. The first CAROLS flight on 28 April 2009 took place at the end of a marked rainfall episode. For this date, the retrieved SSM was high and exceeded $0.40 \mathrm{~m}^{3} \mathrm{~m}^{-3}$ at the central part of the transect. The end of the 2009 campaign was relatively dry, and the last rainfall events (24-26 May 2009) triggered an increase of the retrieved SSM in the central part of transect only. In 2010 two marked rainfall episodes occurred from 29 April to 14 May and from 6 June to 19 June. At the end of May 2010,
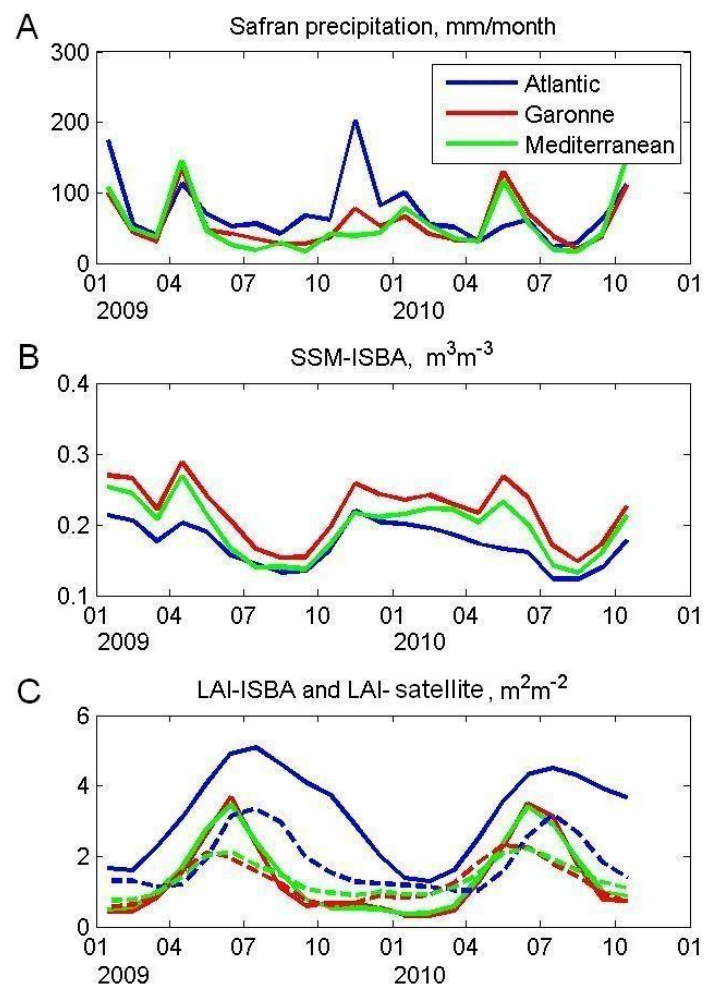

Fig. 5. Spatial and temporal variability of (A) precipitation (SAFRAN reanalysis), (B) ISBA-A-gs surface soil moisture and (C) ISBA-A-gs and satellite-derived LAI (solid and dashed lines, respectively), during the 2009-2010 period, over the three regions covered by the CAROLS Atlantic-Mediterranean transect (Atlantic, Garonne, Mediterranean). Monthly values are plotted.

more local precipitation events took place in different parts of the transect.

Figure 6 presents the retrieved CAROLS SSM along the Atlantic-Mediterranean transect in contrasting 2009 and 2010 conditions (end of April and end of May), together with the SSM simulated by ISBA-A-gs. At the end of April, the CAROLS SSM values observed in 2009 are systematically higher than the 2010 values. At the end of May, the CAROLS SSM is higher in 2009 close to the Atlantic coast and for the eastern part of the transect, and lower at the central part of the transect. The same differences between 2010 and 2009 can be observed in Fig. 6 for the simulated SSM. Also, the spatial distribution of the CAROLS SSM measurements is in good agreement with that of the modelled SSM. The lowest SSM values are observed in the forested Atlantic part of the transect and close to the Mediterranean coast. Table 2 shows that the spatial correlation between the two datasets is significant ( $\mathrm{p}$-value $<0.05$ ) for all 20 flights, with correlation coefficients ranging from 0.36 to 0.85 and root mean square differences (RMSD) ranging from 0.05 to $0.20 \mathrm{~m}^{3} \mathrm{~m}^{-3}$. On average, $R M S D=0.083 \mathrm{~m}^{3} \mathrm{~m}^{-3}$ and $\mathrm{SDD}=0.066 \mathrm{~m}^{3} \mathrm{~m}^{-3}$. For 14 flights out of 20, there is a very good agreement (pvalue $<0.001$ ) between the CAROLS and ISBA-A-gs SSM 
Table 2. Spatial correlation coefficient $(R)$, p-value, RMSD and SDD $\left(\mathrm{m}^{3} \mathrm{~m}^{-3}\right.$ for SSM) and number of grid cells taken for score calculation $\left(N_{\text {obs }}\right)$ between ISBA-A-gs and CAROLS SSM and VOD for 20 flights in 2009 and 2010.

\begin{tabular}{|c|c|c|c|c|c|c|c|c|c|}
\hline \multirow[b]{2}{*}{ Date } & \multicolumn{4}{|c|}{ SSM } & \multicolumn{4}{|c|}{ VOD } & \multirow[b]{2}{*}{$N_{\text {obs }}$} \\
\hline & $R$ & $\mathrm{p}$-value & $\begin{array}{c}\text { RMSD } \\
\left(\mathrm{m}^{3} \mathrm{~m}^{-3}\right)\end{array}$ & $\begin{array}{c}\text { SDD } \\
\left(\mathrm{m}^{3} \mathrm{~m}^{-3}\right)\end{array}$ & $R$ & $\mathrm{p}$-value & $\begin{array}{c}\text { RMSD } \\
(-)\end{array}$ & $\begin{array}{l}\text { SDD } \\
(-)\end{array}$ & \\
\hline 28 Apr 2009 & 0.37 & $* *$ & 0.084 & 0.083 & 0.57 & $* * * *$ & 0.056 & 0.055 & 67 \\
\hline 15 May 2009 & 0.61 & $* * * *$ & 0.098 & 0.073 & 0.48 & $* * * *$ & 0.079 & 0.053 & 68 \\
\hline 18 May 2009 & 0.61 & $* * *$ & 0.066 & 0.065 & 0.57 & $* * *$ & 0.063 & 0.058 & 40 \\
\hline 20 May 2009 & 0.56 & $* *$ & 0.056 & 0.052 & 0.55 & $* *$ & 0.080 & 0.064 & 33 \\
\hline 26 May 2009 & 0.37 & $*$ & 0.092 & 0.067 & 0.48 & $* * *$ & 0.077 & 0.066 & 48 \\
\hline 27 May 2009 & 0.57 & $* * * *$ & 0.070 & 0.063 & 0.49 & $* * * *$ & 0.075 & 0.058 & 67 \\
\hline 15 Apr 2010 & 0.41 & $* *$ & 0.077 & 0.067 & 0.56 & $* * * *$ & 0.052 & 0.051 & 68 \\
\hline 28 Apr 2010 & 0.36 & $* *$ & 0.059 & 0.050 & 0.61 & $* * * *$ & 0.055 & 0.055 & 68 \\
\hline 3 May 2010 & 0.38 & $*$ & 0.197 & 0.137 & 0.01 & NS & 0.218 & 0.126 & 60 \\
\hline 9 May 2010 & 0.61 & $* * * *$ & 0.088 & 0.068 & 0.43 & $* * *$ & 0.081 & 0.081 & 66 \\
\hline 21 May 2010 & 0.70 & $* * * *$ & 0.061 & 0.059 & 0.38 & $* * *$ & 0.064 & 0.060 & 68 \\
\hline 26 May 2010 & 0.85 & $* * * *$ & 0.074 & 0.062 & 0.32 & $*$ & 0.082 & 0.080 & 57 \\
\hline 31 May 2010 & 0.43 & $* * *$ & 0.084 & 0.076 & 0.51 & $* * * *$ & 0.077 & 0.052 & 71 \\
\hline 4 Jun 2010 & 0.74 & $* * * *$ & 0.061 & 0.042 & 0.61 & $* * * *$ & 0.083 & 0.048 & 66 \\
\hline 8 Jun 2010 & 0.52 & $* * *$ & 0.101 & 0.063 & 0.18 & NS & 0.120 & 0.094 & 70 \\
\hline 13 Jun 2010 & 0.80 & $* * * *$ & 0.088 & 0.079 & 0.37 & $* *$ & 0.074 & 0.055 & 73 \\
\hline 18 Jun 2010 & 0.65 & $* * * *$ & 0.086 & 0.085 & 0.31 & $* *$ & 0.089 & 0.066 & 69 \\
\hline 22 Jun 2010 & 0.78 & $* * * *$ & 0.106 & 0.060 & 0.48 & $* * * *$ & 0.066 & 0.056 & 76 \\
\hline 26 Jun 2010 & 0.70 & $* * * *$ & 0.066 & 0.028 & -0.17 & NS & 0.154 & 0.037 & $62 / 22$ \\
\hline 1 Jul 2010 & 0.80 & $* * * *$ & 0.049 & 0.040 & 0.57 & $* * * *$ & 0.082 & 0.046 & 65 \\
\hline Average & 0.59 & - & 0.083 & 0.066 & 0.49 & - & 0.073 & 0.059 & - \\
\hline
\end{tabular}

$*, * *, * * *, * * * *$ stand for $\mathrm{p}$-value between 0.05 and 0.01 , between 0.01 and 0.001 , between 0.001 and 0.0001 and below 0.0001 , respectively. Note that only 22 ISBA-A-gs grid cells presented successful VOD retrievals on 26 June 2010 . The average significant score values are indicated.

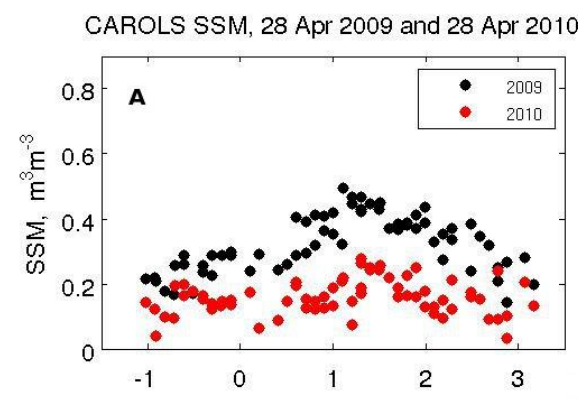

ISBA SSM, SSM, 28 Apr 2009 and 28 Apr 2010

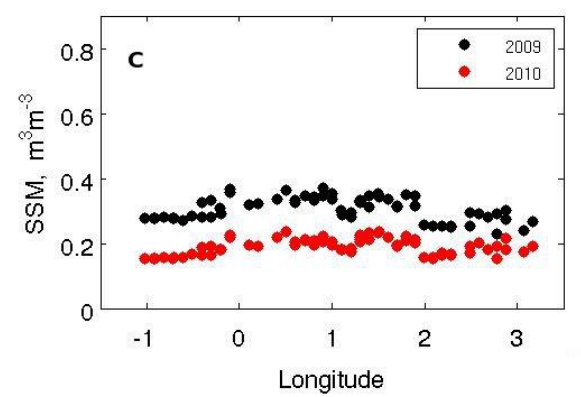

CAROLS SSM, 27 May 2009 and 26 May 2010

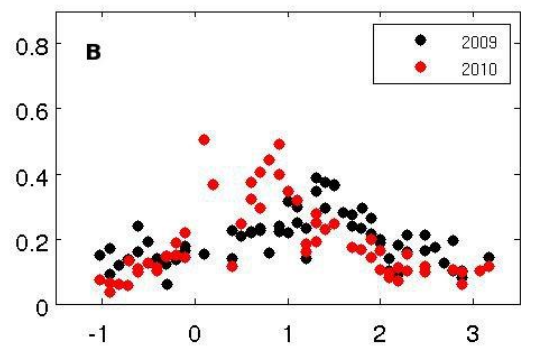

ISBA SSM, 27 May 2009 and 26 May 2010

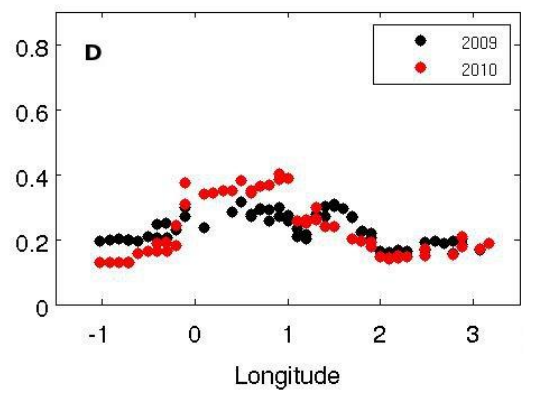

Fig. 6. Flight transect of the surface soil moisture from (A, B) CAROLS retrievals and from (C, D) ISBA-A-gs simulations, at (A, C) the end of April 2010, and (B, D) the end of May 2010. 

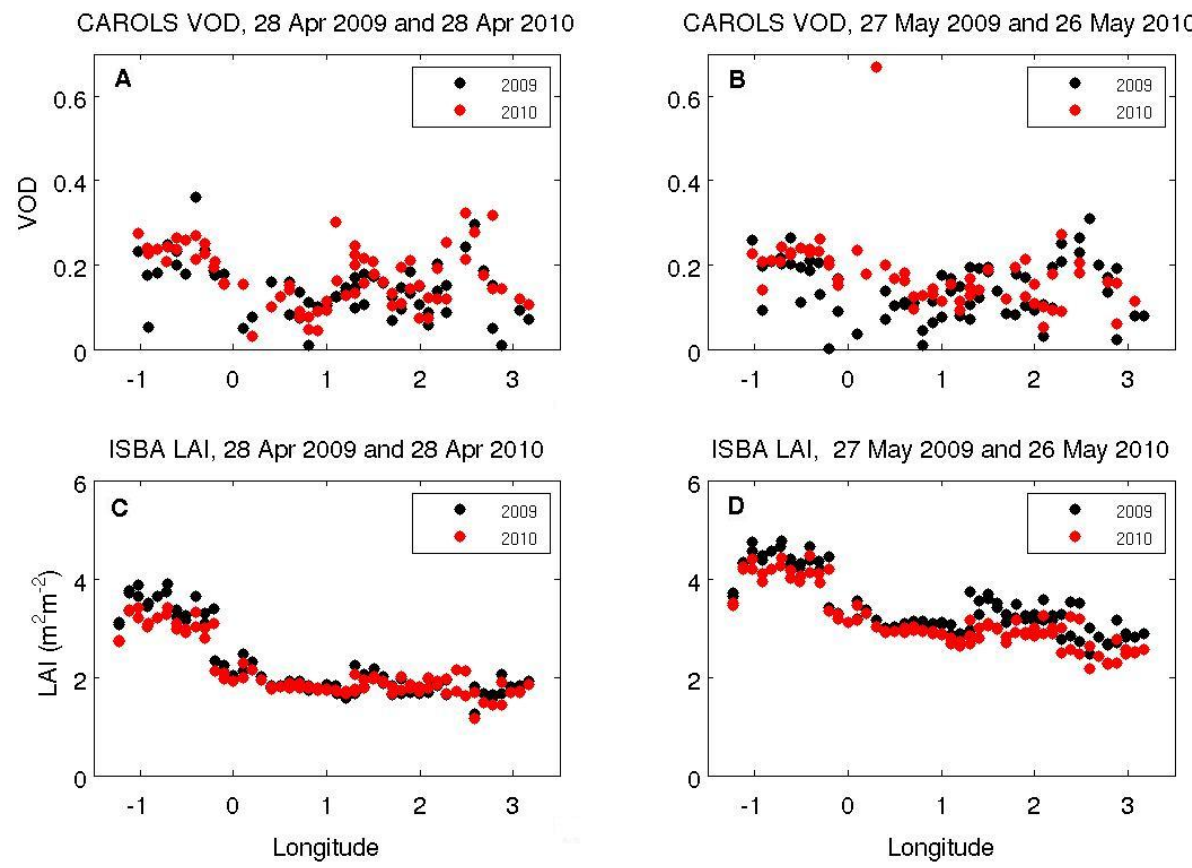

Fig. 7. Flight transect of (A, B) the vegetation optical thickness (VOD) retrieved from CAROLS Tb and of (C, D) the ISBA-A-gs LAI simulations, at (A, C) the end of April 2010, and (B, D) the end of May 2010.

spatial distribution, with $r$ ranging from 0.43 to 0.85 . For these flights, the mean SDD value is $0.062 \mathrm{~m}^{3} \mathrm{~m}^{-3}$. The six remaining CAROLS SSM transects do not correlate very well with the simulated SSM and present higher p-values: 28 April 2009, 20 May 2009, 26 May 2009, 15 April 2010, 28 April 2010, and 3 May 2010. Figure 6 illustrates the disagreement between the simulated and observed SSM spatial patterns on 28 April 2009 and 28 April 2010. For these dates, the CAROLS retrievals present a more pronounced spatial variability than the simulations. This discrepancy can be caused by uncertainties in both retrievals and simulations.

\subsubsection{LAI and VOD}

The VOD values retrieved from CAROLS $\mathrm{Tb}$ range from 0.05 to 0.35 . The highest VOD values are found in forested areas, presenting an average VOD value of 0.2. The arable lands are characterised by relatively low VOD values varying between 0.05 and 0.15 . Figure 7 shows that the ISBA-A-gs simulated LAI increases sharply in 2009 and in 2010, from the end of April to the end of May, from $0.8 \mathrm{~m}^{2} \mathrm{~m}^{-2}$ in Les Landes forest to $1.2 \mathrm{~m}^{2} \mathrm{~m}^{-2}$ in the other parts of the transect. In 2010, the airborne campaign lasted 2.5 months and the simulated LAI increases, on average, from about $2 \mathrm{~m}^{2} \mathrm{~m}^{-2}$ in Les Landes forest, to $2.6 \mathrm{~m}^{2} \mathrm{~m}^{-2}$ in the central agricultural part of the transect, and to $1.8 \mathrm{~m}^{2} \mathrm{~m}^{-2}$ in the eastern Mediterranean part. However, the CAROLS VOD retrievals do not show marked changes during these periods. For most grid cells, the temporal variability of the retrieved VOD, either seasonal or interannual, is very low and not significant (Fig. 7).

In spite of the lack of temporal correlation between the CAROLS VOD and the ISBA-A-gs LAI, the spatial correlation between the two quantities is significant for 19 flights, with $r$ ranging from 0.34 to 0.85 (not shown). The slope of this relationship changes with time (Fig. 8), decreasing from April to July (Table 3). The comparison of the VOD spatial distribution with the 10-day satellite-derived LAI confirms this tendency (Fig. 8). However, in this case the spatial correlation is significant at the end of the 2010 campaign only.

For the same flights, a significant correlation is found between the VWC derived from the ISBA-A-gs simulations (Eq. 3) and the VOD derived from the CAROLS observations. Inverting Eq. (4) for these flights, mean values of $b_{\text {high }}=0.16 \pm 0.03 \mathrm{~m}^{2} \mathrm{~kg}^{-1}$ and $b_{\text {low }}=0.09 \pm 0.07 \mathrm{~m}^{2} \mathrm{~kg}^{-1}$ are obtained. The spatial correlation between the CAROLS VOD and the aggregated model-derived VOD is significant for 17 flights, with correlation coefficients varying from 0.31 to 0.61 (Fig. 8 and Table 2). The mean SDD value is 0.059 . Highly significant correlations (pvalue $<0.001$ ) are found for 13 flights. For these flights, the mean SDD value is 0.057 . Seven CAROLS VOD transects do not correlate very well with the simulated VOD and present higher p-values: 20 May 2009, 3 May 2010, 26 May 2010, 8 June 2010, 13 June 2010, 18 June 2010, 26 June 2010. Among them, only two are associated with rather poor SSM spatial correlations: 20 May 2009 and 3 May 2010. For these two flights, the CAROLS observations 
A

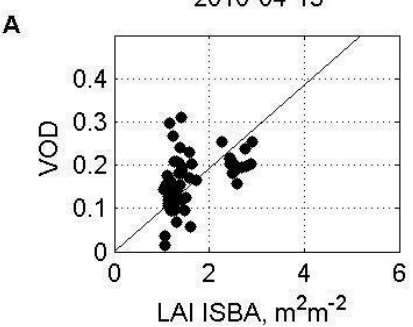

B

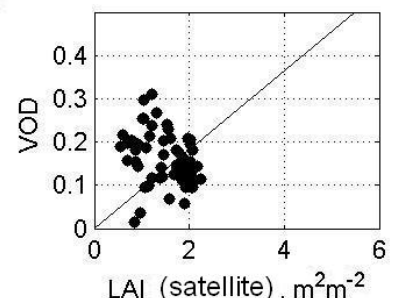

C

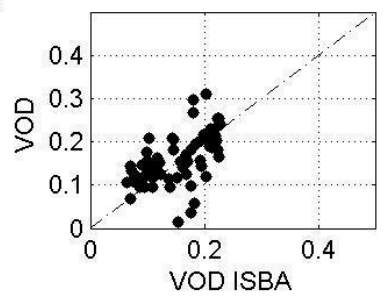

2010-06-04
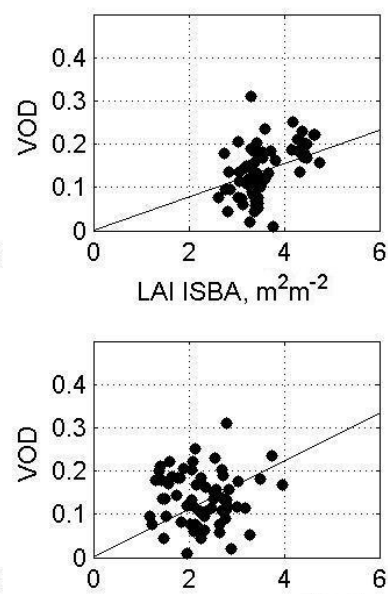

LAl (satellite), $\mathrm{m}^{2} \mathrm{~m}^{-2}$

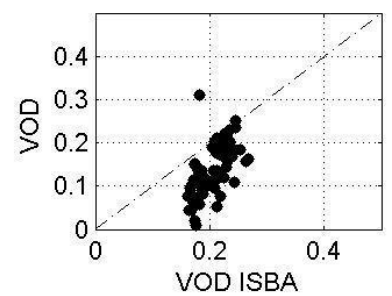

2010-07-01
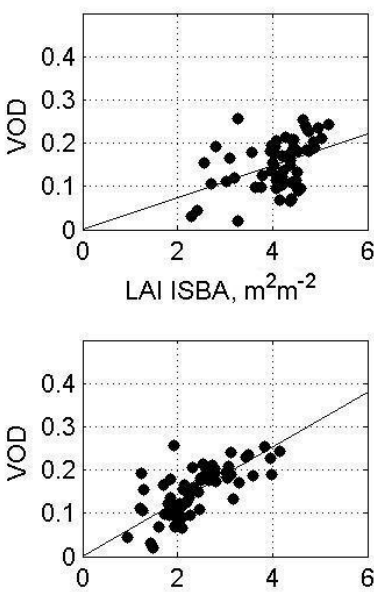

LAl (satellite), $\mathrm{m}^{2} \mathrm{~m}^{-2}$

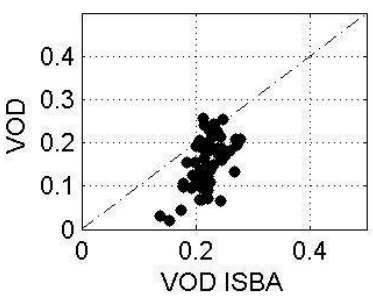

Fig. 8. Spatial correlation between the CAROLS VOD and (A) the ISBA-A-gs LAI, $(\mathbf{B})$ the satellite-derived LAI, and (C) the VOD estimated from the ISBA-A-gs LAI and the forest fraction from ECOCLIMAP-II using the same $b_{\text {low }}$ parameter 0.09 for three dates in 2010 (from left to right): 15 April, 4 June, 1 July. The solid lines on plots (A) and (B) represent linear regression lines with forced zero intercept.

Table 3. Spatial correlation coefficient $(R)$, p-value, RMSD, and the slopes of the regression lines (Fig. 8) between ISBA-A-gs/satellite derived LAI and the CAROLS VOD.

\begin{tabular}{lcccc}
\hline Date & $\mathrm{R}$ & $\mathrm{p}$-value & RMSD & slope \\
\hline \multicolumn{5}{c}{ ISBA-A-gs LAI } \\
\hline 15 Apr 2010 & 0.48 & $* * * *$ & 1.48 & 0.096 \\
4 Jun 2010 & 0.48 & $* * * *$ & 3.44 & 0.039 \\
1 Jul 2010 & 0.44 & $* * *$ & 4.03 & 0.037 \\
\hline \multicolumn{5}{c}{ Satellite-derived LAI } \\
\hline 15 Apr 2010 & - & NS & 1.46 & 0.091 \\
4 Jun 2010 & 0.02 & NS & 2.23 & 0.056 \\
1 Jul 2010 & 0.70 & $* * * *$ & 2.32 & 0.063 \\
\hline
\end{tabular}

$* *, * * *, * * * *$ stand for $\mathrm{p}$-value between 0.01 and 0.001

between 0.001 and 0.0001 and below 0.0001 , respectively. The linear regression, with forced zero intercept (Fig. 8), fails for the flight of 15 April 2010

were markedly affected by RFI along the whole transect, and it is likely that the filtering technique described in Sect. 2.1.4 was not able to screen out all the perturbations. On 8 June 2010, the RFI affected two zones in the middle of the transect. They were not that strong and did not stop the retrieval of either SSM or VOD values, but they affected the retrieval accuracy, especially for VOD. On 26 June 2010, only 22 CAROLS VOD retrievals were successful, mainly at the westernmost and easternmost parts of the transect. Figure 9 shows that the spatial distribution of the CAROLS VOD retrievals aggregated at the grid-cell level is consistent with the simulated VOD for high vegetation. From 28 April 2010 to 4 June 2010, the simulated VOD for low vegetation increases significantly and this increase does not appear in the CAROLS VOD retrievals.

\subsection{Small-scale spatial heterogeneity of SSM and VOD}

In order to assess the local heterogeneity of SSM and VOD, we calculated and analysed the standard deviation (std) of the CAROLS retrievals within each ISBA-A-gs grid cell, using the oversampling capability of the instrument (see Sect. 2.4). For $83 \%$ of the model's grid cells std(SSM) and std(VOD) present relatively low values: $\operatorname{std}(\mathrm{SSM}) \leq 0.05 \mathrm{~m}^{3} \mathrm{~m}^{-3}$ and $\operatorname{std}(\mathrm{VOD}) \leq 0.05$. High values of std(SSM) and std(VOD) are found for $5 \%$ of the model's grid cells: $\operatorname{std}(\mathrm{SSM})>0.08 \mathrm{~m}^{3} \mathrm{~m}^{-3}$ and $\operatorname{std}(\mathrm{VOD})>0.08$. The grid cells presenting the highest sub-grid variability are found on the western part of the transect, in Les Landes forest area. In the central part of the transect, they are found close to the Auch city (between Peyrusse and Lahas in Fig. 1), and 

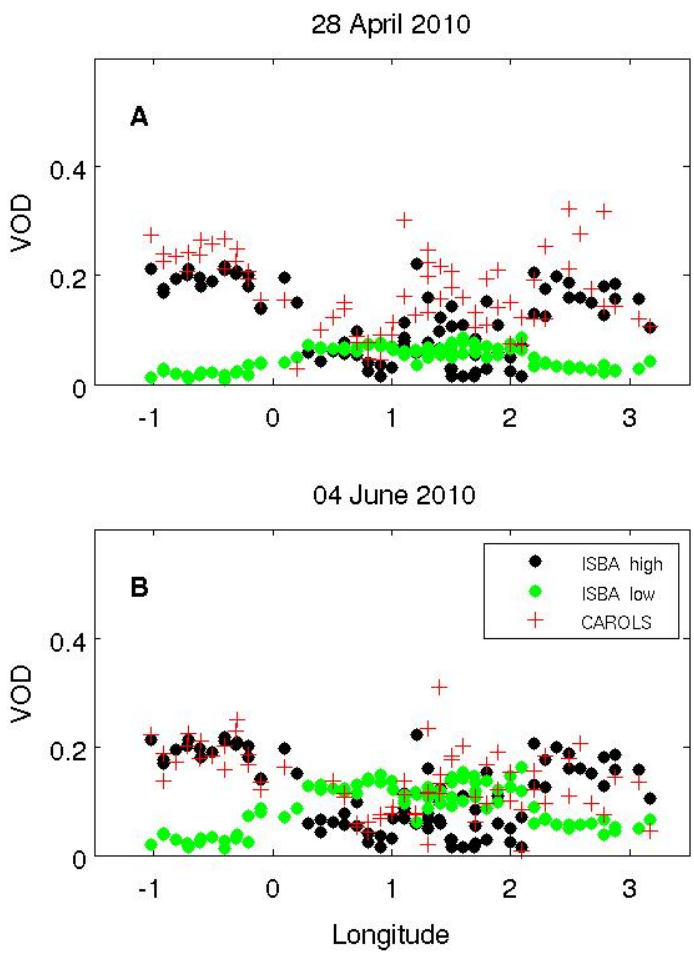

Fig. 9. Along-track variability of the CAROLS VOD and the VOD estimated using the ISBA-A-gs LAI of low vegetation, and the forest fraction from ECOCLIMAP-II and $b$ parameter $=0.09$ for low vegetation and 0.16 for high vegetation, for (A) 28 April 2010 and (B) 4 June 2010.

close to the Garonne River valley. In the eastern part of the transect, they are found in the hilly areas with a high fraction of bare soil and deciduous forests.

\section{Discussion}

\subsection{Causes of mismatch between SSM estimates}

The CAROLS SSM retrievals may present significant biases with respect to the in situ SMOSMANIA observations (Table 1 and Fig. 4), and to the ISBA-A-gs simulations (Fig. 6). Part of these differences may be caused by the spatial heterogeneity of SSM, which is not fully represented in any of the SSM estimates considered in this study (Sect. 3.3). Also, as shown by Fig. 10, large-scale geographic patterns, such as soil texture and vegetation types, may trigger systematic differences in the representation of soil moisture.

The CAROLS transect is very long $(385 \mathrm{~km})$, and sampling soil moisture using ground observations over the whole transect was not feasible. This is why sparse automatic ground observations were associated with simulated SSM values in this study. However, during the campaign, an effort was made to perform additional manual SSM observations at three contrasting sites (Le Mona, Lahage and Berat) close to the Lahas SMOSMANIA station, for nine CAROLS flights ( 3 in 2009 and 6 in 2010). These data were compared with the CAROLS Tb by Albergel et al. (2011). They found that the average SSM at each site correlated well with CAROLS retrievals based on semi-empirical statistical relationships, except for the Berat agricultural site. Indeed, this site was less representative of the area where distributed in situ measurements were taken, as it consisted of large flat maize fields with mainly bare soil in April and May, and rapidly growing maize in June. More research is needed to analyse the CAROLS observations over these sites. In particular, the SSM observations made over hilly terrain at the Le Mona site could be used to investigate the impact of topography on the spatial variation of SSM (Yang et al., 2012).

Along the Atlantic-Mediterranean CAROLS transect, the SSM difference between CAROLS and the ISBA-A-gs model is consistent with the CAROLS SSM departure from the in situ observations. This indicates that the CAROLS SSM retrievals behave differently from the other two SSM estimates. Although the mean bias (of 20 flights) between the CAROLS and ISBA-A-gs SSM is low and equal to $-0.02 \mathrm{~m}^{3} \mathrm{~m}^{-3}$, it presents a high spatial variability with a standard deviation of $0.07 \mathrm{~m}^{3} \mathrm{~m}^{-3}$. The same spatial distribution of the bias is observed for all the flights (not shown). The best agreement between airborne measurements and model simulations is found in the Mediterranean part of the transect with an average bias between these datasets less than $0.01 \mathrm{~m}^{3} \mathrm{~m}^{-3}$. In the Armagnac region at the western part of the transect, between $0.5^{\circ} \mathrm{W}$ and $1^{\circ} \mathrm{E}$, the CAROLS SSM retrievals are constantly lower, of about $-0.06 \mathrm{~m}^{3} \mathrm{~m}^{-3}$, on average. On the other hand, a positive bias of about $0.05 \mathrm{~m}^{3} \mathrm{~m}^{-3}$ is observed over the Garonne River valley at the centre of the transect, between $1^{\circ} \mathrm{E}$ and $1.5^{\circ} \mathrm{E}$. This area is characterised by the highest discrepancy between the CAROLS and ISBA-A-gs SSM estimates, and the maximal difference can reach $0.38 \mathrm{~m}^{3} \mathrm{~m}^{-3}$. It must be noted that, although physical and statistical filters were applied to the CAROLS dataset in order to mitigate the perturbing factors (see Sects. 2.1.4 and 2.3), the influence on SSM of open waters like river channels or small ponds has not been fully eliminated (Sect. 3.3). Using high-resolution Landsat GeoCover Mosaic images, it was checked that areas with individual SSM reaching $0.5 \mathrm{~m}^{3} \mathrm{~m}^{-3}$ in Fig. 2 correspond to regions presenting a high density of small water bodies. Also, the lower CAROLS SSM values in the western part of the transect may be the signature of possible unfiltered low-level RFI. These perturbing factors can also be an issue for SMOS. The physical filter used in this study cannot be applied to SMOS since valid SMOS observations close to nadir are scarce. The statistical approach could be used for SMOS Tb filtering, provided specific threshold curves are developed. Indeed, the threshold curve of Fig. 3 is valid for an incidence angle of $33.5^{\circ}$ and cannot be used at other incidence angles. Also, the threshold curve is valid for southwestern France 


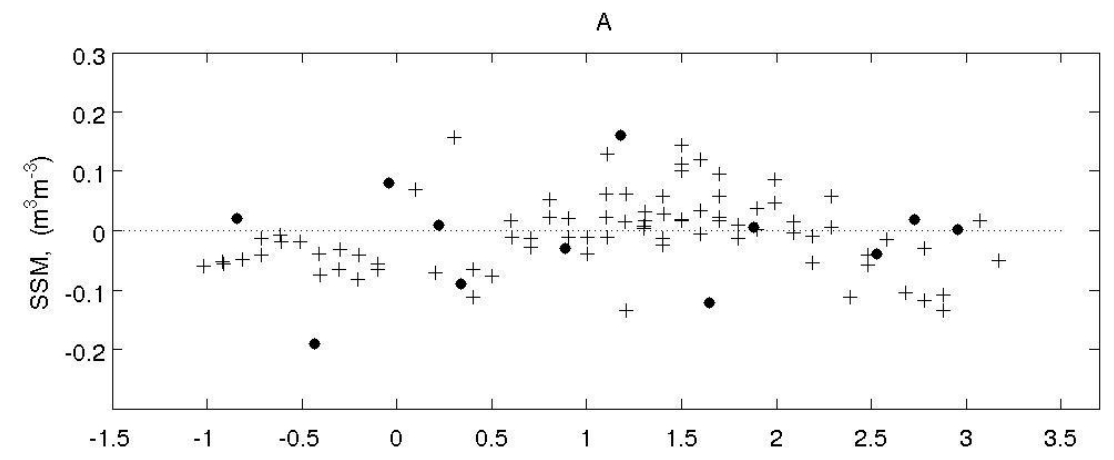

B

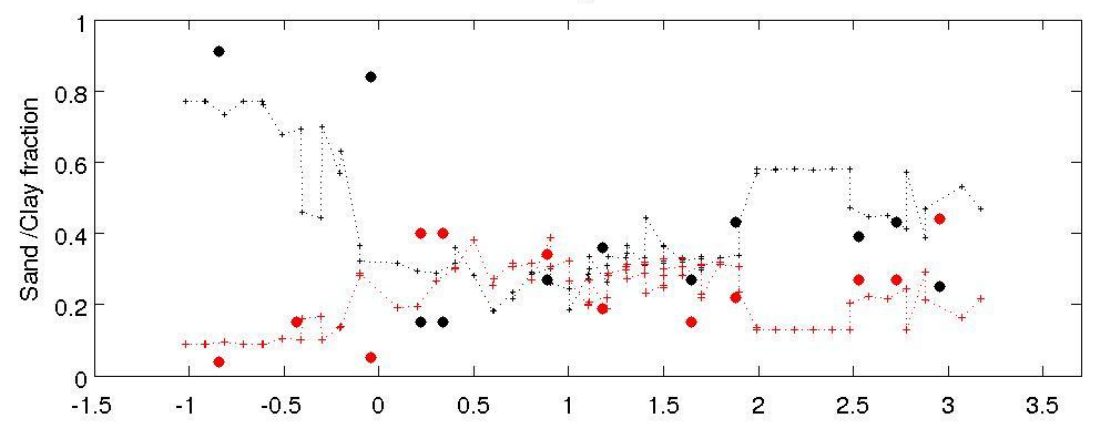

C

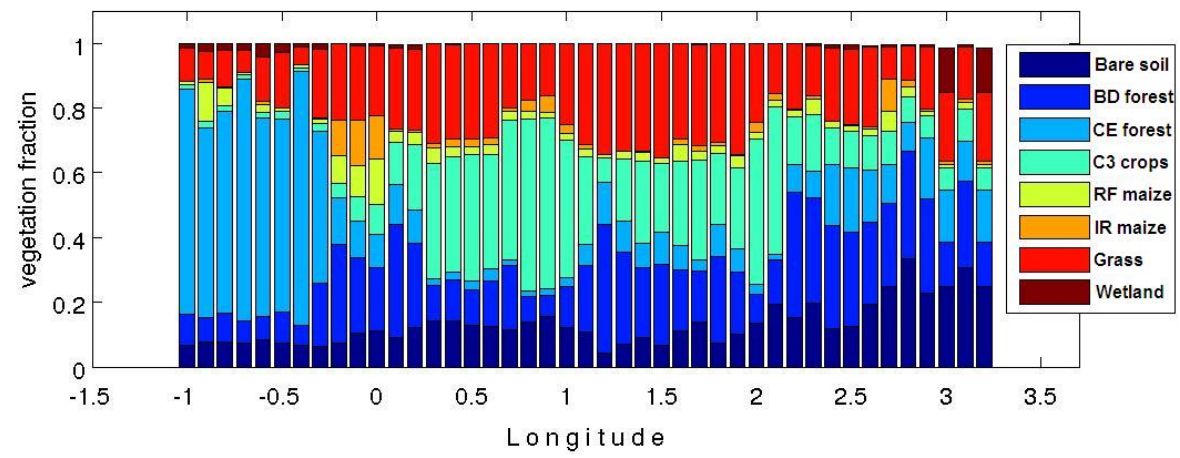

Fig. 10. Spatial variability (A) of the CAROLS minus ISBA-A-gs (crosses) and CAROLS minus SMOSMANIA (dots) bias averaged for 20 flights; (B)sand (black) and clay (red) fraction used for ISBA-A-gs simulations (line) and CAROLS retrievals (dots); (C) fraction of surface types (bare soil, broadleaf deciduous forest, coniferous evergreen forest, C3 crops, rainfed maize, irrigated maize, grasslands, wetlands) from ECOCLIMAP-II.

and it is likely that performing the same exercise in other regions of the globe would give different results.

To some extent, the large-scale spatial patterns in the CAROLS/ISBA-A-gs SSM bias (Fig. 10) can be explained by uncertainties related to the L-MEB inversion process. Indeed, key processes affecting the microwave emission are not represented, such as the topography and its impact on the angular signature of $\mathrm{Tb}$ and on the spatial distribution of soil moisture. Also, a number of studies have shown that it is difficult to represent litters in L-MEB (Saleh et al., 2006a, 2007). The latter factor may affect all the vegetation types, but grasslands and forests tend to favour the formation of a litter. Finally, soil roughness may vary from one vegetation type to another, and also within a given vegetation type. Figure 10 suggests that high values of either the sand proportion of the soil or the fraction of forest tend to match the areas where the CAROLS SSM values are lower than the simulated ones. This may denote the limit of using the single Eq. (1) to represent soil roughness over all the CAROLS transect. Pardé et al. (2011b) have shown that the accuracy of the soil moisture retrieval from CAROLS Tb observations can be improved, up to $0.053 \mathrm{~m}^{3} \mathrm{~m}^{-3}$, through local soil roughness calibration. 


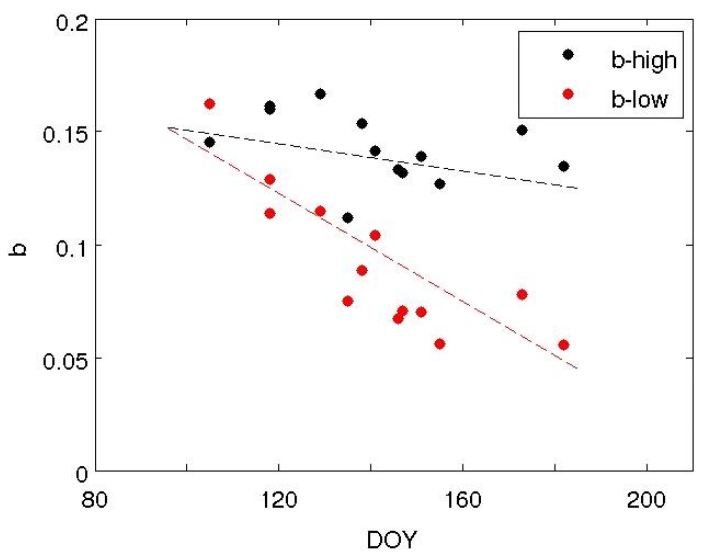

Fig. 11. Temporal variation of the $b$ parameter (in units of $\mathrm{m}^{2} \mathrm{~kg}^{-1}$ ) for high and low vegetation. Time is in day of year (DOY) 2010. For $b_{\text {high }}$ the correlation is insignificant with $r=-0.37$; for $b_{\text {low }}$ the correlation is significant ( $\mathrm{p}$-value $=0.0003$ and $r=-0.85$ ); the trend in $b_{\text {low }}$ is significant at the $0.1 \%$ level and equal to $-0.0012 \mathrm{~m}^{2} \mathrm{~kg}^{-1} \mathrm{day}^{-1}$.

The same kind of problem may exist in the ISBA-A-gs simulations. However, the main factors affecting SSM are accounted for by the model. The maximum SSM and the rate at which SSM varies after a rain, in relation to the rootzone soil moisture value, depend on pedotransfer functions driven by soil characteristics such as soil texture (Noilhan and Lacarrère, 1995). The model uses a map of soil properties and represents the interception of rain by the vegetation.

\subsection{L-band $b$ values through time and vegetation covers}

The $b$ parameter for low vegetation obtained in this study $\left(b_{\text {low }}=0.09 \pm 0.07 \mathrm{~m}^{2} \mathrm{~kg}^{-1}\right.$ ) is close to the value $0.12 \pm 0.03 \mathrm{~m}^{2} \mathrm{~kg}^{-1}$ that was found to be representative of most agricultural crops by Wigneron et al. (2007). On the other hand, the estimated $b$ parameter for high vegetation $\left(b_{\text {high }}=0.16 \pm 0.03 \mathrm{~m}^{2} \mathrm{~kg}^{-1}\right)$ is lower than the value of $0.33 \mathrm{~m}^{2} \mathrm{~kg}^{-1}$ reported in Pellarin et al. (2003a), or than the range of values $\left(0.26\right.$ to $\left.0.34 \mathrm{~m}^{2} \mathrm{~kg}^{-1}\right)$ used to retrieve VOD of high vegetation from SMOS measurements (Kerr et al., 2001). Moreover, Fig. 8 and Table 3 show that the CAROLS VOD retrievals correlate with both LAI observations and aggregated LAI simulations, and that the VOD sensitivity to LAI (either observed or modelled) tends to decrease along the growing season.

The model simulations permit the analysis of the sub-grid variability of the $b$ parameter and to distinguish the temporal evolution of $b_{\text {low }}$ and $b_{\text {high }}$ (Fig. 11). Indeed, forest VOD values are generally not correlated with LAI (e.g. Grant et al., 2008). In particular, the simulated forest VOD does not depend on LAI (Eqs. 3b, and 4b) and does not present seasonal variations. The use of the ECOCLIMAP-II land cover information permits the simulation of separate contributions of low vegetation and forests to the simulated VOD (Figs. 8-9).
While the flight to flight variability of $b_{\text {high }}$ is small, the $b_{\text {low }}$ values present a significant seasonal trend (Fig. 11) and range from values close to $0.15 \mathrm{~m}^{2} \mathrm{~kg}^{-1}$ in April, to values close to $0.05 \mathrm{~m}^{2} \mathrm{~kg}^{-1}$ in summertime. The $b_{\text {low }}$ trend is significant and equal to $-0.0012 \mathrm{~m}^{2} \mathrm{~kg}^{-1} \mathrm{day}^{-1}$. The decrease of $b_{\text {low }}$ during the vegetation period compensates for the rise in VWC, and this may explain the absence of significant temporal variability in the CAROLS VOD retrievals (Figs. 7 and 9).

It must be noted that the ISBA-A-gs model simulates the green LAI, and that Eq. (3a) was derived by Pellarin et al. (2003b) from field data over a variety of crops, with a VWC to LAI ratio of $0.5 \mathrm{~kg} \mathrm{~m}^{-2}$. For the SMOSREX grassland, de Rosnay et al. (2006) and Saleh et al. (2006b) found very good correlations between the green vegetation VWC and the green LAI ( $r^{2}$ close to 0.9$)$, with VWC to LAI ratio values ranging between 0.3 and $0.4 \mathrm{LAI} \mathrm{kg} \mathrm{m}^{-2}$. An attempt was made (not shown) to use such values for grasslands in deriving VOD estimates from ISBA-A-gs simulations. This tended to degrade the scores presented in Table 2 for the VOD spatial correlation. Therefore, the same value of $0.5 \mathrm{~kg} \mathrm{~m}^{-2}$ (Eq. 3a) was used for both grasslands and crops. The presence of dead vegetation residues may affect VWC and tends to reduce the correlation of VWC with LAI (de Rosnay et al., 2006). In this study, we focused on the plant growing period, and it was assumed that most low vegetation covers consisted of green vegetation.

Overall, this study tends to confirm that the L-band VOD relationship with vegetation characteristics is less straightforward than at C-band or X-band. In addition to the reduced sensitivity to VWC, the L-band $b$ value is found to present a seasonal variability for low vegetation canopies. This finding is consistent with the microwave observations over a wheat field analysed by Wigneron et al. (1996). The L-band $b$ values given by Wigneron et al. (1996) for a wheat field range from $0.125 \mathrm{~m}^{2} \mathrm{~kg}^{-1}$ for green vegetation at the start of the growing season, to $0.040 \mathrm{~m}^{2} \mathrm{~kg}^{-1}$ at the end of June. Expressing $b$ as $b=A \varepsilon_{\mathrm{S}}^{\prime \prime} f$ (see Sect. 1), this could be explained by changes in the value of the $A$ coefficient, related to the canopy structure, and to leaf microwave properties, from the growing phase to the senescence.

\subsection{Impact of surface conditions on the retrievals}

Overall, SSM SDD values and to a lesser extent VOD SDD values tend to increase in wet conditions. Figure 12 shows that the SSM SDD is significantly correlated with the CAROLS SSM $\left(r^{2}=0.44\right.$, p-value $\left.<0.01\right)$. For VOD, no significant trend is observed $\left(r^{2}=0.10\right)$. This is consistent with the findings of Pellarin et al. (2003a) regarding the L-MEB retrievals. They showed that (1) for VOD values higher than 0.1 , the value of SSM impacts the success of the SSM retrievals, and (2) the retrieval performance is lower in wet conditions. Indeed, the weaker L-band emission of a wet soil is more easily attenuated by the vegetation. This study confirms that surface conditions have to be accounted for in 


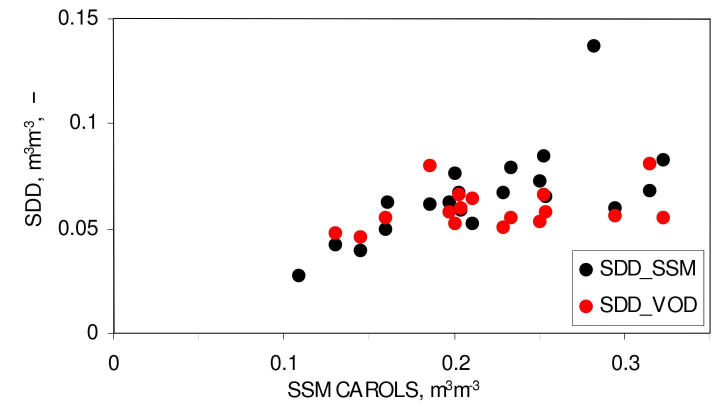

Fig. 12. Impact of SSM conditions (as observed by CAROLS) on the spatial standard deviation of differences (SDD) between the CAROLS SSM and VOD and the simulated values (Table 2, only for $\mathrm{p}$-value $<0.05)$.

assessing the uncertainty of the SMOS SSM and VOD retrievals (Wigneron et al., 2000).

\section{Conclusions}

In this paper we have presented an analysis of the data acquired during the CAROLS flights that took place in southwestern France between the Atlantic and the Mediterranean coasts, in April-May 2009 and in April-July 2010. These data were acquired to validate the retrieval algorithm used for the L2 SMOS SSM processing, and to investigate the accuracy of L-band soil moisture sensing over a large area presenting variable soil and vegetation conditions.

The microwave L-band Tb were affected by RFI. A postprocessing filtering, based on the $\mathrm{TbH}$ vs. $\mathrm{TbV}$ analysis at nadir and slant-looking angles, improved the SSM and VOD retrievals. After applying this filtering, a significant (at the $1 \%$ level) temporal correlation between the airborne SSM and in situ SSM observations was achieved at 6 locations (out of 11), with $r$ values ranging from 0.62 to 0.82 , and SDD values ranging from 0.039 to $0.105 \mathrm{~m}^{3} \mathrm{~m}^{-3}$. Moreover, the spatial variability of the airborne SSM and VOD retrievals was consistent with the ISBA-A-gs simulations. For 18 out of 20 flights, the spatial correlation between ISBA-A-gs and CAROLS SSM was significant at the $1 \%$ level, with $r$ and SDD values ranging between 0.36 and 0.85 and between 0.028 and $0.085 \mathrm{~m}^{3} \mathrm{~m}^{-3}$, respectively.

The sub-grid variability of CAROLS SSM and VOD within ISBA-A-gs grid cells was relatively low. Along the Atlantic-Mediterranean transect, $83 \%$ of ISBA grid cells presented a spatial variability of CAROLS SSM retrievals lower than $0.05 \mathrm{~m}^{3} \mathrm{~m}^{-3}$, a figure comparable with the accuracy acceptable for remotely sensed SSM estimates (Walker and Houser, 2004). It was found that small water bodies (100-300 $\mathrm{m}$ in length) had a significant impact on the CAROLS measurements.

The results of this work show the potential of the L-band to monitor SSM over large regions. On the other hand, the
L-MEB optimisation technique depends on hypotheses, particularly on soil roughness, and this may affect the quality of the SSM retrievals. Also, it is shown that deriving VWC estimates from VOD retrievals is difficult, because forest and herbaceous vegetation present contrasting VWC responses to VOD. Finally, it was found that the $b$ parameter for low vegetation may present a seasonal variation from springtime to summertime and this effect should be investigated further as it is currently not accounted for in L-band microwave emission models.

Acknowledgements. This work was supported by the STAE (Sciences et Technologies pour l'Aéronautique et l'Espace) foundation, in the framework of the CYMENT project, as well as by Centre National d'Etudes Spatiales (CNES) and Météo-France. The CAROLS project was funded by the "Programme Terre Océan Surface Continentales et Atmosphère" (TOSCA, CNES). The ATR-42 aircraft was operated by the SAFIRE UMS 2859. S. Lafont was supported by the GEOLAND2 project, co-funded by European Commission within the GMES initiative in FP7. The authors would like to thank Richard de Jeu (VUA) and one anonymous referee for their fruitful comments.

Edited by: L. Wang

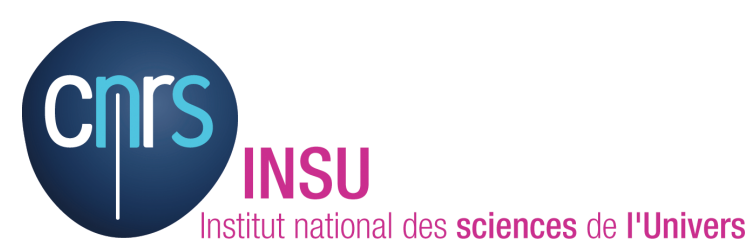

The publication of this article is financed by CNRS-INSU.

\section{References}

Albergel, C., Rüdiger, C., Pellarin, T., Calvet, J.-C., Fritz, N., Froissard, F., Suquia, D., Petitpa, A., Piguet, B., and Martin, E.: From near-surface to root-zone soil moisture using an exponential filter: an assessment of the method based on in-situ observations and model simulations, Hydrol. Earth Syst. Sci., 12, 1323-1337, doi:10.5194/hess-12-1323-2008, 2008.

Albergel, C., Rüdiger, C., Carrer, D., Calvet, J.-C., Fritz, N., Naeimi, V., Bartalis, Z., and Hasenauer, S.: An evaluation of ASCAT surface soil moisture products with in-situ observations in Southwestern France, Hydrol. Earth Syst. Sci., 13, 115-124, doi:10.5194/hess-13-115-2009, 2009.

Albergel, C., Calvet, J.-C., de Rosnay, P., Balsamo, G., Wagner, W., Hasenauer, S., Naeimi, V., Martin, E., Bazile, E., Bouyssel, F., and Mahfouf, J.-F.: Cross-evaluation of modelled and remotely sensed surface soil moisture with in situ data in southwestern France, Hydrol. Earth Syst. Sci., 14, 2177-2191, doi:10.5194/hess-14-2177-2010, 2010.

Albergel, C., Zakharova, E., Calvet, J.-C., Zribi, M., Pardé, M., Wigneron, J.-P., Novello, N., Kerr, Y., Mialon, A., and Fritz, N.: A first assessment of the SMOS data in Southwestern France using in situ and airborne soil moisture estimates: the CAROLS 
airborne campaign, Remote Sens. Environ., 115, 2718-2728, doi:10.1016/j.rse.2011.06.012, 2011.

Baret, F., Makhmara, H., Lacaze, R., and Smets, B.: Biopar Product User Manual: LAI, FAPAR, Fcover NDVI Version 1 from SPOT/VEGETATION data, GEOLAND2 FP7 project, available at: http://web.vgt.vito.be/documents/BioPar/, last access: May 2012.

Bircher, S., Balling, J. E., Skou, N., and Kerr, Y.: Validation of SMOS brightness temperatures during the HOBE airborne campaign, Western Denmark, IEEE T. Geosci. Remote, 50, 14681482, doi:10.1109/TGRS.2011.2170177, 2012.

Brut, A., Rüdiger, C., Lafont, S., Roujean, J.-L., Calvet, J.-C., Jarlan, L., Gibelin, A.-L., Albergel, C., Le Moigne, P., Soussana, J.-F., Klumpp, K., Guyon, D., Wigneron, J.-P., and Ceschia, E.: Modelling LAI at a regional scale with ISBA-A-gs: comparison with satellite-derived LAI over southwestern France, Biogeosciences, 6, 1389-1404, doi:10.5194/bg-6-1389-2009, 2009.

Calvet, J.-C.: Investigating soil and atmospheric plant water stress using physiological and micrometeorological data, Agr. Forest Meteorol., 103, 229-247, 2000.

Calvet, J.-C. and Soussana, J.-F.: Modelling $\mathrm{CO}_{2}$-enrichment effects using an interactive vegetation SVAT scheme, Agr. Forest Meteorol., 108, 129-152, 2001.

Calvet, J.-C., Noilhan, J., Roujean, J.-L., Bessemoulin, P., Cabelguenne, M., Olioso, A., and Wigneron, J.-P.: An interactive vegetation SVAT model tested against data from six contrasting sites, Agr. Forest Meteorol., 92, 73-95, 1998.

Calvet, J.-C., Rivalland, V., Picon-Cochard, C., and Guehl, J.M.: Modelling forest transpiration and $\mathrm{CO}_{2}$ fluxes - response to soil moisture stress, Agr. Forest Meteorol., 124, 143-156, doi:10.1016/j.agrformet.2004.01.007, 2004.

Calvet, J.-C., Fritz, N., Froissard, F., Suquia, D., Petitpa, A., and Piguet, B.: In-situ soil moisture observations for the CAL/VAL of SMOS: the SMOSMANIA network, International Geoscience and Remote Sensing Symposium, IGARSS, Barcelona, Spain, 1196-1199, doi:10.1109/IGARSS.2007.4423019, 2328 July 2007.

Calvet, J.-C., Wigneron, J.-P., Walker, J., Karbou, F., Chanzy, A., and Albergel, C.: Sensitivity of passive microwave observations to soil moisture and vegetation water content: Lband to W-band, IEEE T. Geosci. Remote, 49, 1190-1199, doi:10.1109/TGRS.2010.2050488, 2011.

Cano, A., Saleh, K., Wigneron, J. P., Antol'ın, C., Ballinge, J., Kerr, Y., Kruszewski, A., Millîan-Scheiding, C., Søbjærge, S., Skoue, N., and L'opez-Baeza, E.: The SMOS Mediterranean Ecosystem L-Band characterisation EXperiment (MELBEX-I) over natural shrubs, Remote Sens. Environ., 114, 844-853, 2010.

Chanzy, A., Schmugge, T. J., Calvet, J.-C., Kerr, Y., van Oevelen, P., Grosjean, O., and Wang, J. R.: Airborne microwave radiometry on a semi-arid area during HAPEX-Sahel, J. Hydrol., 188-189, 285-309, 1997.

De Rosnay, P., Calvet, J.-C., Kerr, Y., Wigneron, J. P., Lemaître, F., Escorihuela, M. J., Munoz Sabater, J., Saleh, K., Barrie, J., Coret, L., Cherel, G., Dedieu, G., Durbe, R., Fritz, N., Froissard, F., Kruszewski, A., Lavenu, F., Suquia, D., and Waldteufel, P.: SMOSREX: A long term field campaign experiment for soil moisture and land surface processes remote sensing, Remote Sens. Environ., 102, 377-389, 2006.
De Rosnay, P., Gruhier, C., Timouk, F., Baup, F., Mougin, E., Hiernaux, P., Kergoat, L., and LeDantec, V.: Multi-scale soil moisture measurements at the Gourma meso-scale site in Mali, J. Hydrol., 375, 241-252, 2009.

Dobson, M. C., Ulaby, F. T., Hallikainen, M. T., and El-Rayes, M. A.: Microwave dielectric behaviour of wet soil - Part II: dielectric mixing models, IEEE T. Geosci. Remote, GE-23, 35-46, 1985.

Draper, C. S., Walker, J. P., Steinle, P. J., de Jeu, R., and Holmes, T.: An evaluation of AMSR-E derived soil moisture over Australia, Remote Sens. Environ., 113, 703-710, 2007.

Drusch, M., Wood, E. F., Gao, H., and Thiele, A.: Soil moisture retrieval during the Southern Great Plains Hydrologic Experiment 1999: A comparison between experimental remote sensing data and operational products, Water Resour. Res., 40, W02504, doi:10.1029/2003WR002441, 2004.

Durand, Y., Brun, E., Merindol, L., Guyomarch, G., Lesaffre, B., and Martin, E.: A meteorological estimation of relevant parameters for snow models, Ann. Glaciol., 18, 65-71, 1993.

Faroux, S., Roujean, J.-L., Kaptué, A., and Masson, V.: La base de données de paramètres de surface ECOCLIMAP-II sur l'Europe, Note de centre du Groupe de Météorologie à Moyenne Echelle, 86, Météo-France, CNRM, Toulouse, France, 120 pp., 2009.

Grant, J. P., Saleh-Contell, K., Wigneron, J. P., Guglielmetti, M., Kerr, Y., Schwank, M., Skou, N., and Van de Griend, A. A.: Calibration of the L-MEB model over a coniferous and a deciduous forest, IEEE T. Geosci. Remote, 46, 808-818, 2008.

Gruhier, C., de Rosnay, P., Hasenauer, S., Holmes, T., de Jeu, R., Kerr, Y., Mougin, E., Njoku, E., Timouk, F., Wagner, W., and Zribi, M.: Soil moisture active and passive microwave products: intercomparison and evaluation over a Sahelian site, Hydrol. Earth Syst. Sci., 14, 141-156, doi:10.5194/hess-14-1412010, 2010.

Guglielmetti, M., Schwank, M., Mätzler, C., Oberdörster, C., Vanderborght, J., and Flühler, H.: FOSMEX: Forest soil moisture experiments with microwave radiometry, IEEE T. Geosci. Remote, 46, 727-735, doi:10.1109/TGRS.2007.914797, 2008.

Jackson, T., Hawley, M. E., Shuie, J., O’Neill, P. E., Owe, M., Delnore, S. V., and Lawrence, R. W.: Assessment of preplanting soil moisture using airborne microwave sensors, Hydrologic Applications of Space Technology, Proceedings of the Cocoa Beach Workshop, Florida, August 1985, IAHS Publ., 160, 111-118, 1986.

Jackson, T. J. and Schmugge, T. J.: Vegetation effects on the microwave emission of soils, Remote Sens. Environ., 36, 203-212, 1991.

Jain, A. K., Murty, M. N., and Flynn, P. J.: Data clustering: a review, ACM Comput. Surv., 31, 264-323, 1999.

Jones, O., Jones, L., Kimball, J., and McDonald, K.: Satellite passive microwave remote sensing for monitoring global land surface phenology, Remote Sens. Environ., 115, 1102-1114, 2011.

Kerr, Y. H. and Wigneron, J.-P.: Vegetation models and observations, a review, in: Passive Microwave Remote Sensing of LandAtmosphere Interactions, edited by: Choudhury, B. J., Kerr, Y. H., Njoku, E. G., and Pampaloni, P., VSP, Utrecht, The Netherlands, 317-344, 1995.

Kerr, Y., Waldteufel, P., Wigneron, J.-P., Martinuzzi, J.-M., Font, J., and Berger, M.: Soil moisture retrieval from space: the soil moisture and ocean salinity (SMOS) mission, IEEE T. Geosci. 
Remote, 39, 1729-1736, 2001.

Kirdyashev, K. P., Chukhlantsev, A. A., and Shutko, A. M.: Microwave radiation of the Earth's surface in the presence of vegetation cover, Radio Eng. Electron. Phys., 24, 256-264, 1979.

Kochendorfer, J. P. and Ramírez, J. A.: Modeling the monthly mean soil-water balance with a statistical-dynamical ecohydrology model as coupled to a two-component canopy model, Hydrol. Earth Syst. Sci., 14, 2099-2120, doi:10.5194/hess-14-20992010, 2010.

Lee, K., Burke, Eleanor J., Shuttleworth, W., and Harlow, R.: Influence of vegetation on SMOS mission retrievals, Hydrol. Earth Syst. Sci., 6, 153-166, doi:10.5194/hess-6-153-2002, 2002.

Liu, Y., De Jeu, R. A. M., Van Dijk, A. I. J. M., and Owe, M.: TRMM-TMI satellite observed soil moisture and vegetation density (1998-2005) show strong connection with El Nino in eastern Australia, Geophys. Res. Lett., 34, L15401, doi:10.1029/2007GL030311, 2007.

Liu, Y., De Jeu, R. A. M., McCabe, M. F., Evans, J. P., and Van Dijk, A. I. J. M.: Global long-term passive microwave satellite based retrievals of vegetation optical depth, Geophys. Res. Lett., 38, L18402, doi:10.1029/2011GL048684, 2011.

Masson, V., Champeaux, J.-L., Chauvin, F., Meriguet, C., and Lacaze, R.: A global database of land surface parameters at 1-km resolution in meteorological and climate models, J. Climate, 16, 1261-1282, 2003.

Miralles, D. G., Holmes, T. R. H., De Jeu, R. A. M., Gash, J. H., Meesters, A. G. C. A., and Dolman, A. J.: Global land-surface evaporation estimated from satellite-based observations, Hydrol. Earth Syst. Sci., 15, 453-469, doi:10.5194/hess-15-453-2011, 2011.

Mohr, K. I., Famiglietti, J. S., Boone, A., and Starks, P. J.: Modeling soil moisture and surface flux variability with an untuned land surface scheme: A case study from the Southern Great Plains 1997 Hydrology Experiment, J. Hydrometeorol., 1, 154-169, 2000.

Njoku, E. G. and Chan, S. K.: Vegetation and surface roughness effects on AMSR-E land observations, Remote Sens. Environ., 100, 190-199, 2006.

Njoku, E. G. and Kong, J.-A.: Theory for passive microwave remote sensing of near-surface soil moisture, J. Geophys. Res., 82, 3108-3118, doi:10.1029/jb082i020p03108, 1977.

Noilhan, J. and Lacarrère, P.: GCM gridscale evaporation from mesoscale modelling, J. Climate, 8, 206-223, 1995.

Panceira, R., Walker, J. P., Kalma, J. D., Kim, E. J., Hacker, J. M., Merlin, O., Berger, M., and Skou, N.: The NAFE'05/CoSMOS data set: toward SMOS soil moisture retrieval, downscaling and assimilation, IEEE T. Geosci. Remote, 46, 736-746, 2008.

Panciera, R., Walker, J. P., Kalma, J. D., Kim, E. J., Saleh, K., and Wigneron, J.-P.: Evaluation of the SMOS L-MEB passive microwave soil moisture retrieval algorithm, Remote Sens. Environ., 113, 435-444, 2009.

Pardé, M., Zribi, M., Fanise, P., and Dechambre, M.: Analysis of RFI issue using the CAROLS L-Band experiment, IEEE T. Geosci. Remote, 49, 1063-1070, 2011a.

Pardé, M., Zribi, M., Wigneron, J. P., Dechambre, M., Fanise, P., Kerr, Y., Crapeau, M., Saleh, K., Calvet, J.-C., Albergel, C., Mialon, A., and Novello, N.: Soil moisture estimations based on airborne CAROLS L-band microwave data, Remote Sens., 3, 25912604, doi:10.3390/rs3122591, 2011 b.
Parrens, M., Zakharova, E., Lafont, S., Calvet, J.-C., Kerr, Y., Wagner, W., and Wigneron, J.-P.: Comparing soil moisture retrievals from SMOS and ASCAT over France, Hydrol. Earth Syst. Sci., 16, 423-440, doi:10.5194/hess-16-423-2012, 2012.

Pellarin, T., Wigneron, J. P., Calvet, J.-C., and Waldteufel, P.: Global soil moisture retrieval from a synthetic L-band brightness temperature data set, J. Geophys. Res., 108, 4364, doi:10.1029/2002JD003086, 2003a.

Pellarin, T., Wigneron, J.-P., Calvet, J.-C., Berger, M., Douville, H., Ferrazzoli, P., Kerr, Y. H., Lopez-Baeza, E., Pulliainen, J., Simmonds, L. P., and Waldteufel, P.: Two-year global simulation of L-band brightness temperatures over land, IEEE T. Geosci. Remote, 41, 2135-2139, 2003b.

Pellarin, T., Calvet, J.-C., and Wagner, W.: Evaluation of ERS scatterometer soil moisture products over a half-degree region in Southwestern France, Geophys. Res. Lett., 33, L17401, doi:10.1029/2006GL027231, 2006.

Porporato, A. and Rodriguez-Iturbe, I.: Ecohydrology - a challenging multidisciplinary research perspective, Hydrolog. Sci. J., 47, 811-821, 2002.

Quintana-Segui, P., Le Moigne, P., Durand, Y., Martin, E., Habets, F., Baillon, M., Canellas, C., Franchistéguy, L., and Morel, S.: Analysis of near surface atmospheric variables: validation of the SAFRAN analysis over France, J. Appl. Meteorol. Clim., 47, 92 107, 2008.

Rüdiger, C., Calvet, J.-C., Gruhier, C., Holmes, T., De Jeu, R., and Wagner, W.: An intercomparison of ERS-Scat and AMSR-E soil moisture observations with model simulations over France, J. Hydrometeorol., 10, 431-447, doi:10.1175/2008JHM997.1, 2009.

Saleh, K., Wigneron, J. P., Calvet, J.-C., Lopez-Baeza, E., Ferrazzoli, P., Berger, M., Wursteisen, P., Simmonds, L., and Miller, J.: The EuroSTARRS airborne campaign in support of the SMOS mission: first results over land surfaces, Int. J. Remote Sens., 25, 177-194, 2004.

Saleh, K., Wigneron, J.-P., de Rosnay, P., Calvet, J.-C., and Kerr, Y.: Semi-empirical regressions at L-band applied to surface soil moisture retrieval over grass, Remote Sens. Environ., 101, 415426, 2006 a.

Saleh, K., Wigneron, J.-P., de Rosnay, P., Calvet, J.-C., Kerr, Y., Waldteufel, P., and Escorihuela, M. J.: Impact of rain interception by vegetation and mulch on the L-band emission of natural grass, Remote Sens. Environ., 101, 127-139, 2006b.

Saleh, K., Wigneron, J.-P., Waldteufel, P., de Rosnay, P., Schwank, M., Calvet, J.-C., and Kerr, Y. H.: Estimates of surface soil moisture under grass covers using L-band radiometry, Remote Sens. Environ., 109, 42-53, 2007.

Saleh, K., Kerr, Y. H., Richaume, P., Escorihuela, M. J., Panciera, R., Delwart, S., Boulet, G., Maisongrande, P., Walker, J. P., Wursteisen, P., and Wigneron, J. P.: Soil moisture retrievals at Lband using a two-step inversion approach (COSMOS/NAFE'05 Experiment), Remote Sens. Environ., 113, 1304-1312, 2009.

Schmugge, T. J. and Jackson, T. J.: A dielectric model of the vegetation effects on the microwave emission from soils, IEEE T. Geosci. Remote, 30, 757-760, doi:10.1109/36.158870, 1992.

Schmugge, T., Jackson, T. J., Kustas, W. P., and Wang, J. R.: Passive microwave remote sensing of soil moisture: results from HAPEX, FIFE and MONSOON 90, J. Photogram. Remote Sens., 47, 127-143, 1992. 
Su, Z., Timmermans, W. J., van der Tol, C., Dost, R., Bianchi, R., Gómez, J. A., House, A., Hajnsek, I., Menenti, M., Magliulo, V., Esposito, M., Haarbrink, R., Bosveld, F., Rothe, R., Baltink, H. K., Vekerdy, Z., Sobrino, J. A., Timmermans, J., van Laake, P., Salama, S., van der Kwast, H., Claassen, E., Stolk, A., Jia, L., Moors, E., Hartogensis, O., and Gillespie, A.: EAGLE 2006 Multi-purpose, multi-angle and multi-sensor in-situ and airborne campaigns over grassland and forest, Hydrol. Earth Syst. Sci., 13, 833-845, doi:10.5194/hess-13-833-2009, 2009.

Wagner, W., Lemoine, G., and Rott, H.: A method of estimating soil moisture from ERS scatterometer and soil data, Remote Sens. Environ., 70, 191-207, 1999a.

Wagner, W., Noll, J., Borgeaud, M., and Rott, H.: Monitoring soil moisture over the Canadian prairies with the ERS scatterometer, IEEE T. Geosci. Remote, 37, 206-216, 1999b.

Wagner, W., Blöschl, G., Pampaloni, P., Calvet, J.-C., Bizzarri, B., Wigneron, J.-P., and Kerr, Y.: Operational readiness of microwave remote sensing of soil moisture for hydrologic applications, Nord. Hydrol., 38, 1-20, 2007.

Walker, J. P. and Houser, P. R.: Requirements of global near surface soil moisture satellite mission: accuracy, repeat time and spatial resolution, Adv. Water Resour., 27, 785-801, 2004.

Wang, J. R. and Choudhury, B. J.: Remote sensing of soil moisture content over bare field at $1.4 \mathrm{GHz}$ frequency, J. Geophys. Res., 86, 5277-5282, 1981.

Wang, L., D’Odorico, P., Evans, J. P., Eldridge, D., McCabe, M. F., Caylor, K. K., and King, E. G.: Dryland ecohydrology and climate change: critical issues and technical advances, Hydrol. Earth Syst. Sci. Discuss., 9, 4777-4825, doi:10.5194/hessd-94777-2012, 2012.

Wigneron, J.-P., Chanzy, A., Calvet, J.-C., and Bruguier, N.: A simple algorithm to retrieve soil moisture and vegetation biomass using passive microwave measurements over crop fields, Remote Sens. Environ., 5, 331-341, 1995.

Wigneron, J.-P., Calvet, J.-C., and Kerr, Y.: Monitoring water interception by crop fields from passive microwave observations, Agr. Forest Meteorol., 80, 177-194, 1996.
Wigneron, J.-P., Waldteufel, P., Chanzy, A., Calvet, J.-C., and Kerr, Y.: Two-Dimensional Microwave Interferometer Retrieval Capabilities over Land Surfaces (SMOS Mission), Remote Sens. Environ., 73, 270-282, 2000.

Wigneron, J.-P., Chanzy, A., Calvet, J.-C., Olioso, A., and Kerr, Y.: Modeling approaches to assimilating $\mathrm{L}$ band passive microwave observations over land surfaces, J. Geophys. Res., 107, 4219, doi:10.1029/2001JD000958, 2002.

Wigneron, J.-P., Kerr, Y., Waldteufel, P., Saleh, K., Escorihuela, M.J., Richaume, P., Ferrazzoli, P., de Rosnay, P., Gurney, R., Calvet, J.-C., Grant, J. P., Guglielmetti, M., Hornbuckle, B., Mätzler, C., Pellarin, T., and Schwankh, M.: L-band microwave emission of the biosphere (L-MEB) model: description and calibration against experimental data sets over crop fields, Remote Sens. Environ., 107, 639-655, 2007.

Wigneron, J.-P., Chanzy, A., de Rosnay, P., Rüdiger, C., and Calvet, J.-C.: Estimating the effective soil temperature at L-band as a function of soil properties, IEEE T. Geosci. Remote, 46, 797801, 2008.

Yang, L., Wei, W., Chen, L., Jia, F., and Mo, B.: Spatial variation of shallow and deep soil moisture in the semi-arid loess hilly area, China, Hydrol. Earth Syst. Sci. Discuss., 9, 4553-4586, doi:10.5194/hessd-9-4553-2012, 2012.

Zhao, D., Kuenzer, C., Fu, C., and Wagner, W.: Evaluation of the ERS scatterometer-derived soil water index to monitor water availability and precipitation distribution at three different scales in China, J. Hydrometeorol., 9, 549-562, 2008.

Zribi, M., Pardé, M., Boutin, J., Fanise, P., Hauser, D., Dechambre, M., Kerr, Y., Leduc-Leballeur, M., Skou, M., Søbjærg, S. S., Albergel, C., Calvet, J.-C., Wigneron, J.-P., Lopez-Baeza, E., Ruis, A., and Tenerelli, J.: CAROLS: a new airborne L-band radiometer for ocean surface and land observations, Sensors, 11, 719-742, 2011. 